\title{
Selection into Credit Markets: Evidence from Agriculture in Mali
}

May 2015

Lori Beaman, Dean Karlan, Bram Thuysbaert, and Christopher Udry ${ }^{1}$

\begin{abstract}
We partnered with a micro-lender in Mali to randomize credit offers at the village level. Then, in no-loan control villages, we gave cash grants to randomly selected households. These grants led to higher agricultural investments and profits, thus showing that liquidity constraints bind with respect to agricultural investment. In loan-villages, we gave grants to a random subset of farmers who, endogenously, did not borrow. These farmers have lower - in fact zero - marginal returns to the grants. Thus we find important heterogeneity in returns to investment and strong evidence that farmers with higher marginal returns to investment self-select into lending programs.
\end{abstract}

JEL: D21, D92, 012, 016, Q12, Q14

Keywords: credit markets; agriculture; returns to capital

\footnotetext{
${ }^{1}$ Lori Beaman: I-beaman@northwestern.edu, Northwestern University; Dean Karlan: dean.karlan@yale.edu, Yale University, IPA, J-PAL, and NBER; bram.thuysbaert@ugent.be, Ghent University; and Christopher Udry: christopher.udry@yale.edu, Yale University. The authors thank partners Save the Children and Soro Yiriwaso for their collaboration. Thanks to Yann Guy, Pierrick Judeaux, Henriette Hanicotte, Nicole Mauriello, and Aissatou Ouedraogo for excellent research assistance and to the field staff of Innovations for Poverty Action - Mali office. We thank Dale Adams, Alex W. Cohen and audiences at the Columbia University, Dartmouth College, the Federal Reserve Bank of Chicago, the University of California-Berkeley, University of California-San Diego, and the University of Maryland for helpful comments. All errors and opinions are our own.
} 


\section{Introduction}

Additional investments in agriculture among poor subsistence farmers in Africa can generate an increase in revenue, particularly with respect to small investments such as fertilizer and improved seeds (Beaman et al. 2013; Duflo, Kremer, and Robinson 2008; Evenson and Gollin 2003; Udry and Anagol 2006). We demonstrate that the return to agricultural investment varies across farmers, farmers are aware of this heterogeneity, and farmers with particularly high returns self-select into borrowing.

High average returns to agricultural investment could emerge when farmers lack capital and face credit constraints. Microcredit organizations have attempted to relieve credit constraints, but most microcredit lenders focus on small business financing. The typical microcredit loan requires frequent, small repayments and therefore does not facilitate investments in agriculture, where income comes as lump sums once or twice a year. By contrast, the loan product studied here is designed for farmers by providing capital at the beginning of the planting season and requiring repayment as a lump sum after the harvest. However, lending may not be sufficient to induce investments in the presence of other constraints. ${ }^{2}$ Farmers may be constrained by a lack of insurance (Karlan et al. 2013), have time inconsistent preferences (Duflo, Kremer, and Robinson 2011), or face high costs of acquiring inputs (Suri 2011). We investigate whether capital constraints are binding among farmers in Mali, and then, critically, if farmers with higher marginal returns to investment are those most likely to borrow.

We use an experiment which offered some farmers access to loans and other farmers unrestricted cash grants. Out of 198 study villages, our partner microcredit organization, Soro Yiriwaso, offered loans in 88 randomly assigned villages. In those "loan" villages, women could get loans by joining a local community association. In the remaining "no-loan" villages, no loans were offered. In the no-loan villages, we randomly selected households to receive grants worth 40,000 FCFA (US\$140). In loan villages, we waited until households (and the associations) had made their loan decisions and then we gave grants to a random subset of those households who did not choose to borrow. We can then compare the average returns to the grant in the

\footnotetext{
${ }^{2}$ The evidence from traditional microcredit, targeting micro enterprises, is mixed: some randomized studies find an increase in investment in self-employment activity (Crepon et al. 2015; Angelucci, Karlan, and Zinman 2015) while others do not (Attanasio et al. 2015; Augsburg et al. 2015; Banerjee et al. 2015; Tarozzi, Desai, and Johnson 2015). See Banerjee, Karlan and Zinman (2015) for an overview of the above six studies. Rarely have randomized evaluations of microcredit found an increase in the profitability of small businesses as a result of access to microcredit, at least at the mean or median (Banerjee et al. 2015; see Crepon et al. 2015 as the exception). These limited results from microcredit come in spite of evidence that the marginal returns to capital can be quite high in micro-enterprise (de Mel, McKenzie, and Woodruff 2008).
} 
representative set of farmers in no-loan villages to the average returns to the grant in the selfselected sample of households who did not take out loans in loan villages. This allows us to test an important question on selection: do those who do not choose to borrow have lower average returns than those who choose to borrow?

The cash grants in no-loan villages led to a significant increase in investments in cultivation. We observe more land being cultivated (8\%), more fertilizer use (14\%), and overall more input expenditures (14\%). These households also experienced an increase in the value of their agricultural output and in profits by $13 \%$ and $12 \%$, respectively. Thus, we observe a significant increase in investments in cultivation and an increase in profits from relaxing capital constraints. This impact on profit even persists after an additional agricultural season. Thus in this environment, capital constraints are limiting investments in cultivation. ${ }^{3}$

In loan villages, households given grants did not earn any higher profits from the farm than households not provided grants. Yet, in the no-loan villages, households given grants had large increases in profits relative to those not provided grants. This suggests that households which borrowed, and were thus selected out of the sample frame in loan villages, had higher marginal returns than those who did not choose to borrow. We also look at other outcomes such as livestock ownership and small business operations. There is no evidence that grant recipients in loan villages are investing the capital in alternative activities more than their counterparts in no-loan villages. We conclude that there are heterogeneous returns across farmers, and specifically that the lending process sorts farmers into higher and lower productivity farmers.

Thus the impacts of cash grants in the loan villages versus no-loan villages reveal important selection effects induced by the lending process. The experimental design allows us to show that farmers who use capital more productively are also more likely to take loans. We can then ask whether this composition effect is predictable by observables. If the heterogeneity is predictable by information observable to the lender ex-ante, then the lender could use this information both for social purposes (to focus their efforts marketing to those who stand the

\footnotetext{
${ }^{3}$ The increase in investment contingent upon receipt of the grant is sufficient to reject neoclassical separation, but not to demonstrate the existence of binding capital constraints. For example, in models akin to Banerjee and Duflo (2012) with an upward-sloping supply of credit each farmer, a capital grant could completely displace borrowing from high-cost lenders, lower the opportunity cost of capital to the farmer and induce greater investment even though the farmer could have borrowed more from the high cost lender and thus was not capital constrained in a strict sense. However, there is no evidence that these grants lowered total borrowing. Therefore, we refer to the range of capital market imperfections that could cause investment responses to cash grants simply as credit constraints.
} 
most to gain, from a poverty alleviation perspective) as well as expand access to credit (i.e., risk-based pricing, to alleviate adverse selection problems).

Related to this question of observables and unobservables, we also examine what aspect of the lending process is creating the positive selection, the self-selection or any peer-selection that occurs due to the group lending model. The experimental design itself does not allow us to separate these mechanisms; however, two facts suggest that the effect is through selfselection, not peer selection.

First, we look at the distribution of returns. We find that whereas in no-loan villages there is no correlation between baseline profits and marginal returns to the grant, in the loan villages, the marginal returns to the grant are close to zero for those with high baseline profits and only positive for those with low baseline profits. If the lender or the peers were selecting borrowers, they would select based on profit level, not marginal profits, since profit levels are more important in determining repayment. Yet the selection effects are occurring only on high-profitlevel farmers. The high-profit, low-marginal-return farmers are those who are not receiving loans. This implies that even after any bank or peer selection occurs (if any) on the level of profits, a selection effect still occurs, and thus is likely driven by self-selection.

Second, we test whether the differential effect of cash grants for farmers in the loan villages (who chose not to borrow) versus the no-loan villages is driven by households with more socially integrated women. Since the community should have superior information about such households, communities would be able to more effectively screen out the low-return households among those who are socially integrated. Using baseline social integration data, we find that the differential effects are not stronger for households with socially integrated women and the differential effect remains after controlling for heterogeneity in baseline social integration, thus suggesting that peers are not screening on expected marginal returns to capital.

We can also estimate the intent-to-treat impacts of offering loans on a range of outcomes. About $21 \%$ of households in our sample received loans (in loan villages), which is a take-up rate far below that of the grants - all households accepted the grants - but similar to other microcredit contexts. Like the grants, we find that offering loans led to an increase in investments in cultivation, particularly fertilizer, insecticides and herbicides, and an increase in agricultural output. We do not detect, however, a statistically significant increase in profits. Therefore we observe farmers investing in cultivation when capital constraints are relaxed through credit. 
These loan impact results are in stark contrast to a long history of failed agricultural credit programs (Adams 1971), which often were implemented as government programs and thus plagued by politics (Adams, Graham, and Von Pischke 1984). In the expansion of microcredit in the 1980s and onward, we have seen several changes occur at once: a shift from individual to group lending processes (although now this trend is reversing (Giné and Karlan 2014; de Quidt, Fetzer, and Ghatak 2012)), a shift from balloon payments to high frequency repayment (Field et al. 2013 study a lending product that partially reverses this trend, with a delayed start to repayments), a shift from government to nongovernment (and now to for-profit) institutions, and a shift from agricultural focus to entrepreneurial focus (Karlan and Morduch 2009; Armendariz de Aghion and Morduch 2010). The loan impact component of this study effectively returns to this older question, but tests an agricultural lending model that is different than had been employed in the past, since there is no government involvement, group liability and also little to no subsidy.

Our results on selection into borrowing also have two important methodological implications. First, they provide evidence of important selection on unobserved variables. For example, to assess the impact of lending to farmers, had we merely matched borrowers to non-borrowers on observable characteristics, we would have overestimated the impact of credit, since conditional on an unusually wide range of observed characteristics those who borrow have higher returns to capital than those who did not borrow. The random choice of communities into which to enter by the lender is sufficient for us to estimate ITT effects of the lending program, avoiding strong assumptions on selection. Building on the arguments of Heckman 2010 (JEL) and Eisenhauer et al (2014 JPE forthcoming), we provide a simple economic model of the selection process and combine this with information generated by the second stage randomization of grants in the random and selected samples to shed light on the nature of the selection process. Second, the results also highlight the pitfalls of estimating treatment-on-thetreated analysis in the credit context, given heterogeneous treatment effects with respect to likelihood of borrowing.

\section{The Setting, experimental design and data}

Agriculture in most of Mali, and in all of our study area, is exclusively rainfed. Evidence from nearby Burkina Faso suggests that income shocks translate into consumption volatility (Kazianga and Udry 2006), so improving agricultural output can have important welfare consequences not only on the level of consumption but also the household's ability to smooth consumption within a year. The main crops grown in the area include millet/sorghum, maize, cotton (mostly grown by men); and rice and groundnuts (mostly grown by women). At baseline, 
about $40 \%$ of households were using fertilizer ${ }^{4}$, and $51 \%$ were using other chemical inputs (herbicides, insecticide).

The loans were marketed, implemented, serviced and financed by Soro Yiriwaso, a Malian microcredit organization (and an affiliate of Save the Children, an international nongovernmental organization based in the United States). The cash grants were implemented by Innovations for Poverty Action. Figure 1 demonstrates the design, and Figure 2 presents the timeline.

\subsection{Experimental design}

The sample frame consisted of 198 villages, located in two cercles (an administrative unit larger than the village but smaller than a region) in the Sikasso region of Mali. ${ }^{5}$ The randomization consisted of two steps: First, we assigned villages to either loan (88) or no-loan (110) treatment. In loan villages, anyone could receive a loan by joining a women's association created for the purpose. Second, after loan participation had been decided, those households who did not borrow were randomly assigned to either receive a grant or not. Below we describe each component in detail.

\section{Loans}

Soro Yiriwaso (SY) offered their standard agricultural loan product, called Prêt de Campagne, in 88 of the study villages (village-level randomization). This product is given exclusively to women, but money is fungible within the household. Unlike most microloan products, it is designed specifically for farmers. Loans are dispersed at the beginning of the agricultural cycle in May-July and repayment occurs after harvest. Administratively the loan is given to groups of women organized into village associations, but each individual woman receives an informal contract with the association. Qualitative interviews with members outside the study villages, prior to the intervention, revealed that the application process is very informal with few

\footnotetext{
${ }^{4}$ The government of Mali introduced heavy fertilizer subsidies in 2008 . The price of fertilizer was fixed to 12,500 FCFA per $50 \mathrm{~kg}$ of fertilizer. This constituted a $20 \%$ to $40 \%$ subsidy, depending on the type of fertilizer and year. Initial usage of the subsidy was low in rural areas initially but grew over time, helping to explain the increase in input expenses we observe in our data from baseline to endline (Druilhe and Barreiro-Huré 2012).

${ }^{5}$ Bougouni and Yanfolila are the two cercles. Both are in the northwest portion of the region and were chosen because they were in the expansion zone of the MFI, Soro Yiriwaso. The sample frame was determined by randomly selecting 198 villages from the 1998 Malian census that met three criteria: (1) were within the planned expansion zone of Soro Yiriwaso, (2) were not currently being serviced by Soro Yiriwaso, and (3) had at least 350 individuals (i.e., sufficient population to generate a lending group).
} 
administrative records at the village level. For example, there are no records of loan applications or denial. Nor is a record kept of more subtle, informal processes of "application" or "denial", such as women who discuss the possibility of joining the group to get a loan but who are discouraged from joining. The size of the group was not constrained from the lender: a group could add a member without decreasing the size of loan each woman received. The size of the loan to each woman was also determined though an informal, iterative process. Repayment is tracked only at the group level, and there is nominally joint liability. On average there are about 30 women per group and typically 1, though up to 3, associations per village. This is a limited liability environment since these households have few assets and the legal environment of Mali would make any formal recourse on the part of the bank nearly impossible. However, given that loans are administered through community associations, the social costs of default could be quite high. In practice we observe no defaults over the two agricultural cycles where we were collaborating with Soro Yiriwaso. ${ }^{6}$

The annual interest rate is $25 \%$ plus $3 \%$ in fees and a mandatory savings of $10 \%$. SY offered loans in the study villages for the 2010 and 2011 agricultural seasons. The average loan size in 2010 was 32,000 FCFA (US\$113). ${ }^{7}$

\section{Grants}

Grants worth 40,000 FCFA (US\$140) were distributed by Innovations for Poverty Action (with no stated relationship to Soro Yiriwaso) to about 1,600 female survey respondents in May and June of the agricultural season of 2010-2011. In the 110 villages not offered loans, households were randomly selected to receive grants and a female household member - to parallel the loans - was always the direct recipient. US\$140 is a large grant: average input expenses, in the absence of the grant, were US\$196 and the value of agricultural output was US\$522. The size of the grant was chosen to closely mimic the size of the average loan provided by Soro Yiriwaso, though ex post the grant ended up being slightly larger on average than loans. In no-loan villages, we also provided some grants to a randomly selected set of men, but we exclude those households from the analysis in this paper. ${ }^{8}$

\footnotetext{
${ }^{6}$ This is not atypical for Soro. In an assessment conducted by Save the Children in 2009, $0 \%$ of Soro's overall portfolio for this loan product was at risk (> 30 days overdue) in years 2004-2006, rising to only .7\% in 2007.

${ }^{7}$ We use the 2011 PPP exchange rate with the Malian FCFA at 284 FCFA per USD throughout the paper.

${ }^{8}$ These data are intended for a separate paper analyzing household dynamics and bargaining, and we do not consider them useful for the analysis here since loans were only given to women.
} 
In loan villages, grant recipients were randomly selected among survey respondents who did not take out a loan. ${ }^{9}$ We attempted to deliver grants at the same time in all villages, but administrative delays on the loan side meant that most grants were delivered first in no-loan villages, and there is an average 20-day difference between when no-loan households received their grants from their counterparts in loan villages. We discuss the implications of this delay in section 3.2.1.

In order to minimize the possibility of dynamic incentives to not borrow, we informed recipients that the grants were a one-time grant, not an ongoing program, and also distributed some grants in loan villages to a few borrowers who were not in the survey, so that it was not obvious that borrowing precluded someone from being a grant recipient.

\subsection{Data}

Figure 2 shows the timeline of the project. The baseline was conducted in January-May 2010. A first follow-up survey was conducted after the first year of treatment and the conclusion of the 2010 agricultural season ${ }^{10}$ in January-May 2011, and a second follow-up survey was conducted after the second year of treatment and the conclusion of the 2011 agricultural season in January-May 2012. In the three rounds, similar survey instruments covered a large set of household characteristics and socioeconomic variables, with a strong focus on agricultural data including cultivated area, input use and production output at individual and household levels. We also collected data on food and non-food expenses of the household as well as on financial activities (formal and informal loans and savings) and livestock holdings.

\footnotetext{
${ }^{9}$ We determined who took out a loan by matching names and basic demographic characteristics from the loan contracts between the client and Soro Yiriwaso, which Soro Yiriwaso shared with us on an ongoing basis. There were a few cases (67) where Soro Yiriwaso allowed late applications for loans and households received both a grant and a loan. The majority (41 out of 67 ) of these cases occurred because there were multiple adult women in the household, and one took out a loan and another received a grant. We include controls for these households. The results are similar if the observations are excluded.

${ }^{10}$ We also conducted an "input survey" on a subsample of the sample frame right after planting in the first year (September-October 2010), in order to collect more accurate data on inputs such as seeds, fertilizer and other chemicals, labor and equipment use. This input survey covered a randomly selected two thirds of our study villages (133 villages) and randomly selected half of the households (stratifying by treatment status) to obtain a subsample of 2,400 households. We use the input survey if conducted, and if not we use the end of season survey. We also control for timing of the collection of the data in all relevant specifications.
} 


\subsection{Randomization, balance check and attrition}

The randomization was done after the baseline using a re-randomization technique ensuring balance on key variables. ${ }^{11}$ The randomization of the provision of grants was done at the household level, while the loan randomization was at the village level. Moreover, we did separate randomization routines for the grant recipients in the loan and no-loan villages. We control for all village and household-level variables used in the re-randomization routine and interactions of the household-level variables with village type (loan or no-loan) in all analyses.

We conduct different tests to verify that there are no important observable differences between the different groups in the sample, using variables not included in the randomization procedure. Appendix Table A1 looks at baseline characteristics across three comparisons: (i) loan to no-loan villages; (ii) grant to no-grant households in no-loan villages; and (iii) grant to no-grant households in loan villages. Few covariates are individually significantly different across the three comparisons, and an aggregate test in which we regress assignment to treatment on the set of 11 covariates fails to reject orthogonality for each of the 3 comparisons ( $p$-value of $0.26,0.91$ and 0.67 , respectively, reported at the bottom of the table).

Our attrition rate is low: approximately one percent each round. Regardless, Appendix Table A2 reports tests for differential attrition comparing the same groups as in Table A1, from baseline to the first follow-up and to the endline. For each of the three comparisons, we fail to reject that attrition rates are on average the same in the compared groups for both follow up years. In a regression of attrition on the nine covariates, treatment status, and the interaction of nine covariates and treatment status, a test that the coefficients on treatment status and the interaction terms are jointly zero fails to reject for all but one of the six regressions (results on bottom row of Appendix Table 2).

\footnotetext{
${ }^{11}$ First, a loop with a set of number of iterations randomly assigned villages to either loan or no-loan, and then we selected the random draw that minimized the t-values for all pairwise othorgonality tests. This is done because of the difficulties stratifying using a block randomization technique with this many baseline variables. The variables used for the loan randomization were: village size, an indicator for whether the village was all Bambara (the dominant ethnic group in the area), distance to a paved road, distance to the nearest market, the percent of households having a plough, the percentage of women having a plough, fertilizer use among women in the village, average literacy rate, and the distance to the nearest health center. For household-level randomization we used: whether the household was part of an extended family; was polygamous; the primary female respondent's: land size, fertilizer use, and whether she had access to a plough; an index of the household's agricultural assets and other assets, and per capita food consumption. See Bruhn and McKenzie (2009) for a more detailed description of the randomization procedure.
} 


\section{Selection into loans}

We focus on agricultural outcomes, so consider agricultural output $Q$. $Q_{B}(Z, E)$ is the output of a household that borrows $\left(q_{\mathrm{B}}, Z\right.$ and $\epsilon$ will denote particular realizations of the random variables $Q_{\mathrm{B}}, Z$ and $E$ ). $Q_{\mathrm{B}}$ depends on a vector of characteristics of the household, $Z$, all of which are known to the household, but which may or may not be observed by the SY lending group in the household's community or the econometrician. Output also depends on the realization of random production shock $E$, which is unknown to either the household or the lender at the time the loan decision is made. Similarly, $Q_{N}(Z, E)$ is the output of a household that does not borrow. Of course, we observe only one of $Q_{\mathrm{B}}$ or $Q_{N}$ for any particular household. The selection process into borrowing depends on the same vector of household characteristics Z; the institutional structure of the SY lending group provides no suggestion that the selection process involves characteristics other than those that may also influence the distribution of output. The household borrows and we observe $Q_{\mathrm{B}}$ if and only if $S(\mathrm{Z}) \geq 0$. The line of research culminating in Heckman and Vytlacil (2005) and Eisenhauer et al (2014) provides a robust approach to understanding the selection process and to estimating important aspects of the joint distribution of $\left(Q_{B}, Q_{N}\right)$. In the context of this credit market, however, we lack suitable exclusion restrictions to directly apply this line of research. Instead, our two-stage randomization provides important information about expected returns to investment conditional on selection (or not), and then in section 4, we add additional structure from a model of the credit market that distinguishes self-selection from lender screening. We show that these different selection processes have distinguishable implications for the observed distribution of farming outcomes for those with and without grants, in the random sample of all households versus in the selected sample of non-borrowers.

In the random set of communities not offered loans, cash grants were distributed to randomly selected households. Compliance with respect to take up of these grants was $100 \%$. Hence there is no selection into the grant program itself. Let $Q_{G}(Z, E)$ be the output for a household that receives a grant and $Q_{N G}(Z, E)$ be the output of a household that does not receive a grant. We assume that $Q_{N G}(Z, E) \equiv Q_{N}(Z, E)$; conditional on the household's characteristics, a household not receiving a grant achieves the same output as a household not borrowing. The household-level randomization of grants permits us to estimate the unconditional expectation $E\left(\mathrm{Q}_{\mathrm{G}}(\mathrm{z}, \epsilon)-\mathrm{Q}_{\mathrm{N}}(\mathrm{z}, \epsilon)\right.$ ), and also the unconditional marginal distributions $F_{\mathrm{G}}\left(\mathrm{q}_{\mathrm{G}}\right)$ and $F_{N}\left(q_{N}\right)$.

Similarly, in the random set of communities offered loans, cash grants were distributed to randomly selected households who did not borrow, e.g. for which $S(Z) \geq 0$, in these communities, we are able to estimate the conditional expectation 
$E\left(Q_{G}(z, \epsilon)-Q_{N}(z, \epsilon) \mid S(z)<0\right)$ and the conditional marginal distributions $F_{\mathrm{G}}\left(\mathrm{q}_{\mathrm{G}} \mid S(z)<0\right)$ and $F_{N}\left(\mathrm{q}_{N} \mid S(z)<0\right)$. In the villages offered loans, $\operatorname{prob}(\mathrm{S}(\mathrm{z})<0)$ is observed, so we can estimate $E\left(Q_{G}(z, \epsilon)-Q_{N}(z, \epsilon) \mid S(z) \geq 0\right)$. Thus we can estimate the returns to cash grants achieved in agriculture by households who select into borrowing, versus those who do not. ${ }^{12}$

\subsection{Observable characteristics of borrowers versus non-borrowers}

Take-up of the loans, determined by matching names from administrative records of Soro Yiriwaso with our sample, was $21 \%$ in the first agricultural season (2010-11) and $22 \%$ in the second (2011-2012). Despite the similarity in overall take-up numbers, there is a lot of turnover in clients. Only about 65\% of clients who borrowed in year 1 took out another loan in year 2 . This overall take-up figure is similar to other evaluations of microcredit focusing on small enterprise (Angelucci, Karlan, and Zinman 2015; Attanasio et al. 2015; Augsburg et al. 2015; Banerjee et al. 2015; Crepon et al. 2015; Tarozzi, Desai, and Johnson 2015). Table 1 provides descriptive statistics from the baseline on households who choose to take out loans in loan villages, compared to non-clients in those villages. Information on the household as a whole as wealth as the primary female respondent and primary male respondent is reported. There is a striking pattern of selection into loan take-up: households that invest more in agriculture, have higher agricultural output and profits, and have more agricultural assets and livestock, are more likely to borrow. Figure 3 demonstrates that this holds across the whole distribution. Women in households who borrow are also more likely to own a business and are more "empowered" by three metrics: they have higher intra-household decision-making power, are more socially integrated and are more engaged in community decisions. ${ }^{13}$ Households that borrow also have higher consumption at baseline than non-clients.

\footnotetext{
${ }^{12}$ If $Q_{G}(Z, E) \equiv Q_{B}(Z, E)$, that is, the grant is used in the same way that a similarly -sized loan would be put, we also can estimate the returns to loans for those who borrow versus those who do not. This is likely too strong an assumption, because households with a variety of possible investments to make would choose to invest a grant differently from a loan.

${ }^{13}$ All three of these variables are indices, normalized by the no-grant households in loan-unavailable villages. The household decision-making index includes questions on how much influence she has on decisions in the following domains: food for the household, children's schooling expenses, their own health, her own travel within the village, and economic activities such as fertilizer purchases and raw materials for small business activities. The community action index includes questions on: how frequently she speaks with different village leaders, and different types of participation in village meetings and activities. The social capital index includes questions about 7 other randomly selected community members from our sample and whether the respondent knows the person, are in the same organization, would engage in informal risk sharing and transfers with the person, and topics of their discussions (if any).
} 


\subsection{Returns to the grant in loan and no-loan villages}

Panel A of Table 2 shows the estimates from the following regression using the two years of follow up data we have on farm investments and output.

$$
\begin{aligned}
& Y_{i j t}=\alpha+\beta_{1} \text { grant }_{i} \cdot I\{t=2011\}+\beta_{2} \text { grant }_{i} \cdot I\{t=2011\} \cdot \text { loan }_{j} \\
& +\beta_{3} \text { grant }_{i} \cdot I\{t=2012\}+\beta_{4} \text { grant }_{i} \cdot I\{t=2012\} \cdot \text { loan }_{j} \\
& +\beta_{5} I\{t=2012\}+\beta_{6} I\{t=2012\} \cdot \operatorname{loan}_{j}+X_{i j t} \pi+\theta_{j}+\varepsilon_{i j t}
\end{aligned}
$$

where grant $_{i}$ indicates individual $i$ received a grant in May-June 2010, and $\operatorname{loan}_{j}$ indicates that the MFI offered loans in village $j . I\{t=2011\}$ is an indicator of the data round. We also include year by village type (loan vs no-loan) controls, and additional baseline controls $(X)$ which include the baseline value of the dependent variable $y_{0}{ }^{14}$ plus its interaction with year by village type, village fixed effects, and stratification controls described in section 2.3 and listed in the notes of the table, and indicators for whether the household received both a grant and loan*year indicators. $\beta_{1}$ and $\beta_{2}$ are the primary coefficients of interest. $\beta_{1}$ is the effect of the cash grant on the outcome $Y_{i j t}$ in the non-loan villages, i.e., the average effect of the cash grant among all potential borrowers. $\beta_{2}$ shows the differential impact of receiving grant on the outcome $Y_{i j t}$ for the households that did not borrow (in loan villages) compared to the random, representative sample in no-loan villages.

Panel A of Table 2 shows the estimates from this regression for a variety of cultivation outcomes (inputs along with harvest output and profits) and Panel A of Table 3 shows the analogous estimates for other, non-cultivation outcomes such as livestock, small business ownership, consumption, and female empowerment.

\subsubsection{Agriculture}

Columns (1)-(6) look at agricultural inputs. We see in the first row that in households who did receive a grant, compared to those who did not in no-loan villages, the amount of land cultivated increased $(0.18 \mathrm{ha}$, se $=0.065)$ a small but significant amount. The grant also induced an increased in hired labor days (2.7 days, se=0.80). 2.7 days is a small number, but these households use very little hired labor: the mean in the control in 2011 is only 17 days throughout the agricultural season. Fertilizer $(\$ 11, \mathrm{se}=4.4)$ and other chemical inputs $(\$ 9$, se=2.2) also increased by 14 and 19 percent respectively. Total input expenses (excluding family labor and the value of land, which are challenging to value) increased by US\$28 (se=8.2), a 14

\footnotetext{
${ }^{14}$ In cases where the observation is missing a baseline value, we instead give the lagged variable a value of -9 and also include an indicator for a missing value.
} 
percent increase. The grants therefore led to an increase in agricultural investment. Columns (7)-(8) show that output and farm profits (excluding the value of family labor and land) also went up significantly. Output went up by 13 percent $(\$ 66, s e=20)$ and profits by 12 percent $(\$ 40$, se $=15)$. Overall, we see significant increases in investments and ultimately profits from relaxing capital constraints. ${ }^{15}$

Table 2 shows that the selected sample of households who did not take out a loan do not experience such positive returns when capital constraints are relaxed. Across the board, the estimates of the impact of the grant in loan villages in 2011 (year 1) are near zero. Column (1) shows that while households in no-loan villages increased the amount of land cultivated as a result of the grant, households in loan villages (who did not take out a loan) by contrast did not ( $\beta_{2}$ is -0.16 ha, se $=0.09$ and the $p$ value of the test that the sum of $\beta_{2}$ and $\beta_{1}$ is zero is 0.85$)$. The interaction term for family labor days $(-9$, se 6$)$, fertilizer expenses $(-\$ 8.8$, se $=6.5)$ and other chemical expenses $(-\$ 7, s e=3)$ are all negative, though only the latter is statistically significant. Total input expenses in loan villages do increase in response to the grant by $\$ 17$ ( $p$ value is $0.06)$, which is not statistically different from the estimate in no-loan villages of $\$ 28$. However, we see no corresponding increase in output nor in profits. The $\beta_{2}$ interaction coefficient for output is similar in magnitude and negative $(-\$ 49.80$, se $=27.7)$, offsetting the increase in output in no-loan villages $(\$ 66, \mathrm{se}=19)$. The test that the sum of the two coefficients is different from zero is not rejected $(p=0.42)$. Similarly for profits, the total effect in loan villages is actually negative $(-\$ 3.78)$ and not significantly different from zero $(p=.81)$. Thus while there is some evidence that among households who did not take out loans, the grant induced some increase in inputs, there is no evidence of increases in agricultural output nor profits - in stark contrast to the random sample of households in no-loan villages.

The analysis indicates that households who are screened out of loans are those without high returns in agriculture to cash transfers. In contrast to the literature on health products, where much of the evidence points towards limited screening benefits from cost sharing (Cohen and Dupas 2010; Tarozzi et al. 2013), we find that the repayment liability does lead lower return

\footnotetext{
${ }^{15}$ We are not estimating the marginal product of capital as in de Mel, McKenzie, and Woodruff (2008) but instead the "total return to capital"- i.e., cash. Beaman et al. (2013) showed in this same area that labor inputs also adjust along with agricultural inputs, making it impossible to separate the returns to capital from the returns to labor without an additional instrument for labor inputs. We are therefore capturing the total change in profits and investment behavior when capital constraints are relaxed but will use the term "returns" when referring to the type of farmers who select into borrowing.
} 
households to be screened out. ${ }^{16}$ The design does not allow us to experimentally determine whether households are self-selecting (demand side) or being screened by the lender / association (supply side). In section 3.4, we will discuss this further and look at the interaction with respect to social integration, and the agricultural profits distribution for each treatment group, to provide us with evidence that the results are driven by self-selection, not peer or bank selection.

\section{Year 2}

We observe a persistent increase in output and profits in the 2011-2012 agricultural season (year 2) from the grant given in 2010, as shown by the $\beta_{3}$ coefficients in Table 2: output is higher in grant recipient households by $\$ 50$ (se $=22$ ) in Column (7) of Table 2 and profits by $\$ 47$ (se=17). This is striking since we do not observe grant-recipient households spending more on inputs in Column $6(\$ 2, \mathrm{se}=10)$. One thing to note, however, is that some of the investments in year 1 may benefit year 2 output. There are also changes in agricultural practices which we may not capture with our measure of input expenses. For example, in 2011 grant-recipient households spend more on purchasing seeds. In 2012 these households spend no more on seeds than control households but they do use a larger quantity of seeds. This could reflect learning but also could reflect the use of hybrid seeds in year 2011 which provide some yield benefits the following year, even without re-purchasing seeds. This highlights that our simple accounting of 2011 profits as 2011 output minus 2011 inputs is imperfect, but we have no way of constructing a depreciation rate for the various inputs. We also see a continued increase in the extensive margin of fertilizer use but not in (average) expenses.

In year 2 , we see a similar negative interaction term, $\beta_{4}$, on profits in Column (8) as in year 1 , which is significant at the $10 \%$ level $(-\$ 39$, se $=22.9)$. The lower profits may be a result of higher input use: Column (6) shows that, in loan villages, grant-recipient households spent more on input expenses $(\$ 27, \mathrm{se}=17.1)$ than control households in 2012 . Although this is not statistically significant compared to the grant recipients in non-loan villages, it is statistically significant compared to control $(p=0.034)$.

\section{Timing}

One concern about our interpretation of the results is that on average, households received grants in loan villages 20 days later than in no-loan villages because of delays in the

\footnotetext{
${ }^{16}$ However, consistent with the literature on subsidies of health products (Dupas 2013; Kremer and Miguel 2004; Ashraf, Berry, and Shapiro 2010), we find demand is dramatically dampened: loan take-up is around $21 \%$ percent while all households accepted the grant.
} 
administration of the loans. If farmers in no-loan villages received grants too late in the agricultural cycle to make productive investments, we would erroneously conclude that there is positive selection into agricultural loans when in reality the result is attributable to our experimental implementation. This is particularly a concern since we observe farmers increase the amount of land they farm, which is a decision which occurs very early in the agricultural cycle. In Appendix Table A3, we look at land cultivated (i.e., an investment decision made early in the process) and an index of all the agricultural outcomes and find no relationship with the timing of the grant, among the grant-recipient households in no-loan villages. ${ }^{17}$

\subsubsection{Other outcomes}

Table 3 shows the estimates of equation (1) looking at outcomes other than agriculture. The most striking result is in Columns (1) and (2): grant-recipients households in no-loan villages are more likely to own livestock (0.11 percentage points, se=0.014), and there is a large ( $\$ 160$, se $=72$ ) increase in the value of total livestock compared to no-grant households. This represents a $10 \%$ increase in the value of household livestock, and is slightly larger than the value of the grant itself. Recall we saw in Table 3 that households also spent an extra \$28 on cultivation investments. The livestock value is measured several months after harvest; these results may indicate that post-harvest, households moved some of their additional farming profits into livestock. ${ }^{18}$ We also find evidence that the grant increased the likelihood in no-loan villages that a recipient household had a small enterprise $(0.038$ percentage points higher, se=0.015), as shown in Column (3). ${ }^{19}$ Grant recipient households also consumed more, including $12 \%$ more food (Column 4, $\$ 0.38$ per day in adult equivalency, se $=0.11$ ) and $6 \%$ in non-food expenditures (Column 5, \$2.95 per month, se=1.4). We find the latter persistent in year 2 but food consumption not. Columns (6)-(9) show no main effect of the grant on whether the

\footnotetext{
${ }^{17}$ We look at two main specifications: one in which we include date the grant was received linearly and with its square, and a second which splits the sample into the first half of the grant period and the second half (since most of the grants in the loan-available villages were distributed in the second half). In both cases we control for whether this was the team's first visit to the village (revisit to village).

${ }^{18}$ We may also over-value recently-purchased livestock which may be younger or smaller in treatment households since we use village-level reports of livestock prices to value livestock quantities for all households.

${ }^{19}$ Appendix Table A4 shows in Column (1) that despite increasing the extensive margin of small business, we do not measure an increase in business profits after year 1 .
} 
household has any financial savings, membership in rotating, savings and loans associations (ROSCAs), education expenses or medical expenses. ${ }^{20}$

The investment and spending patterns among grant recipient households in loan villages for the most part echo those described above in no-loan villages. Column (1) shows that while grant recipients in loan villages were overall more likely to own livestock than their control counterparts, the magnitude of the effect is about half as large as in the no-loan villages (interaction term is -0.046 percentage points, se=0.022). The remainder of the outcomes however shows few differences. ${ }^{21}$

Taken together, Panel A of Table 3 shows that the grants benefited households in a variety of ways. However, we have no strong evidence that households in loan villages, who did not experience higher agricultural output and profits as in no-loan villages, used their grants to invest in alternative higher-return activities other than cultivation.

\section{Year 2}

In year 2 , the coefficients on the impact of the grants in no-loan villages $\left(\beta_{3}\right)$ show persistent impacts for some key outcomes. Columns (1) and (2) demonstrate that grant-recipient households are more likely to own livestock $(0.09$, se=0.015) and continue to hold more livestock assets $(\$ 270$, se $=132)$ than control households in no-loan villages. They are also more likely to own a business ( 3 percentage points, se=0.013). ${ }^{22}$ There is no increase in food consumption in year $2(\$ 0.05$, se $=0.17)$ but an increase in monthly non-food expenditure $(\$ 3.89$, se $=2.12)$. Households are also more likely to have financial savings ( 0.035 percentage points, se $=0.019)$ and be members of rotating savings and loans associations (ROSCAs) $(0.039$

\footnotetext{
${ }^{20}$ Columns (2) through (4) of Appendix Table A4 also show no impact in year 1 on women's empowerment, involvement in community decisions nor social capital, respectively.

21 The only outcome which suggests potential heterogeneity in behavior upon receiving a grant between our random, representative households in no-loan villages and our selected sample in loan villages is medical expenses, in Column (10). Medical expenses (in the last 30 days) are marginally-significantly higher in no-loan grant households $(\$ 4.37$, se $=2.52)$, since medical expenses may have declined $(-\$ 2.54, \mathrm{se}=1.85)$ among grant recipients in loan villages. The total effect in loan villages is not statistically different from zero $(p=0.28)$. This is a difficult outcome to interpret because having more resources could mean a household is more likely to treat illnesses they experience but are also more able to invest in preventative care, making the prediction of the treatment effect ambiguous.

${ }^{22}$ Appendix Table A4 shows in Column (1) that business profits increase by $18 \%(\$ 42$, se $=18.4)$ in year 2 .
} 
percentage points, se $=0.018)$. Columns (9)-(10) show that there continues to be no measurable impact on educational expenses $\left(\$ 0.41\right.$, se=3.64), or medical expenses $(-\$ 0.76, \mathrm{se}=1.80){ }^{23}$

Table 3 shows that, similar to year 1 , there is little evidence of households in no-loan villages using grants differently than those in loan villages across this set of non-agricultural outcomes (livestock ownership, owning a small business, and consumption) in year 2 . There is an alternative hypothesis that the loan selected in people with short-run investments (i.e., those with payoffs within one year), and non-borrowers invested their grants in longer-term investments. However, even by the end of the second year, we do not see profit increases (for non-borrowers in loan villages who receive grants) from enterprise investment, longer-term farm investments, or other long-term investments such as education, to support this hypothesis; nor does the qualitative information from the field support this alternative hypothesis.

\subsection{Unobservable versus observable predictors of marginal returns}

Table 1 demonstrated that loan-takers are systematically different at baseline than those who do not take out loans on a number of characteristics, including those which are surely important in cultivation: they have more land, spend more in inputs, and enjoy higher output and profits. These baseline characteristics may be enough to predict who could most productively use capital on their farm. Theoretically the prediction is ambiguous: many models would predict that those who have the highest returns are households who are the most credit constrained. We observe individuals who take out loans have on average more wealth in the form of livestock. This could mean they have lower returns to investments in cultivation. However, they may also have access to better technologies, like a plough, which could increase their returns to capital.

Here we examine whether the marginal returns from grants and the selection effect discussed above are predicted fully by characteristics observed in the baseline, or if there is additional selection that occurs based on unobservables. We use the same specification as earlier but also include baseline characteristics (Z) interacted with an indicator for receiving a grant, for year 1 and year 2 .

\footnotetext{
${ }^{23}$ Appendix table A4 also suggests no change in intra-household bargaining ( 0.059 of a standard deviation, $\mathrm{se}=0.039$ ) or community action $(0.021, \mathrm{se}=0.045)$. The social capital index in column (4) shows a significant rise of 0.09 of a standard deviation $(\mathrm{se}=0.017)$ in year 2 .
} 


$$
\begin{gathered}
Y_{i j t}=\alpha+\beta_{1} \text { grant }_{i} \cdot I\{t=2011\}+\beta_{2} \text { grant }_{i} \cdot I\{t=2011\} \cdot \text { loan }_{j} \\
+\beta_{3} \text { grant }_{i} \cdot I\{t=2012\}+\beta_{4} \text { grant }_{i} \cdot I\{t=2012\} \cdot \text { loan }_{j}+\gamma_{1} \text { grant }_{i} \cdot Z_{i j t} \cdot I\{t=2011\} \\
+\gamma_{2} \text { grant }_{i} \cdot Z_{i j t} \cdot I\{t=2012\}+\gamma_{3} Z_{i j t} \cdot I\{t=2011\}+\gamma_{4} Z_{i j t} \cdot I\{t=2012\} \\
+\beta_{5} I\{t=2012\}+\beta_{6} I\{t=2012\} \cdot \operatorname{loan}_{j}+X_{i j t} \pi+\theta_{j}+\varepsilon_{i j t}
\end{gathered}
$$

We structure our analysis by sequentially increasing the controls we include in the regression, by first focusing on $Z$ variables which would be fairly observable to microcredit institutions (MFI), then including variables which would be fairly observable to the community and therefore may be included in screening mechanisms which use the community (as in grouplending), and finally adding in our measure of risk aversion.

Table 4 shows our main empirical specification with profits as the outcome, with different baseline household-level controls. Column (1) is identical to Column (8) in Table 2 and is included for ease of comparison. Column (2) adds in Z variables measured at baseline, and their interactions, that an MFI may be able to easily observe: the household's landholdings (in hectares), the value of their own livestock, agricultural profits, an indicator for whether the household has six or more adults (the $90^{\text {th }}$ percentile), an indicator for the presence of an extended family, and the number of children in the household. Column (2) shows that the estimates of the differential effect of the grant in loan versus no-loan villages is reduced in magnitude slightly ( $\$ 36.72$, se $=21.87$ compared to $-\$ 44$ without controls) but continues to be significant at the $10 \%$ level. We show the coefficients from the interactions between some of these $Z$ variables and grant receipt. Strikingly, higher baseline profits do not predict higher returns to the grant, at least on average. We also do not observe a statistically significant relationship between baseline livestock value or land size and returns to the grant. However, larger households do benefit more from the grants in years 1 and 2 than smaller households.

Column (3) adds in additional information which would likely be known within the community: the primary female respondent's intra-household decision-making power, her engagement in community decision-making and her social capital. Finally, Column (4) also adds in a measure of risk aversion. Respondents were asked to choose between a series of lotteries, which vary in terms of their expected value vs risk. We include an indicator for choosing the perfectly safe lottery, which about half the sample chooses. In all specifications, the estimates on the differential impacts of the grants in loan versus no-loan villages are slightly smaller in magnitude but still negative and statistically significant at the $10 \%$ level. We therefore conclude that our estimates of selection effects are not driven by the rich set of observables we measure at the baseline, but by unobservables, such as land productivity, access to complementary inputs, or farmer skill. In the next section we examine whether the selection is a demand-side 
effect (people choosing whether to borrow or not) or a supply-side effect (lenders or peers choosing whether to let a farmer into their lending circle).

\section{Is screening driven by supply-side or demand-side forces?}

In section 3.2 we showed that providing cash grants to households who did not take out loans led to lower agricultural returns - and in fact zero returns - compared to households who were randomly selected in no-loan villages. The experimental design provided us with a transparent method for showing that the impact of the grants on agricultural output in the random sample of households is greater than their impact in the selected sample of non-borrowers. In contrast, the experimental design itself does not allow us to differentiate how the screening itself occurs: it may be the result of self-selection on the part of farmers (demand-side) or due to lender screening on the part of the MFI or community associations (supply-side). ${ }^{24}$

We begin with a simple model to illustrate what we mean by self-selection and by lender screening. In order to distinguish these concepts, the model requires three elements. First, there is a cash in advance constraint that generates a potential demand for credit. Second, some potential conflict of interest between the borrower and the lender is required if selfselection and lender screening are to be distinguished. In this model, the conflict emerges from limited liability. Third, multiple dimensions of heterogeneity across borrowers will generate patterns of self-selection that differ from those caused by lender screening. Self-selection will be largely driven by heterogeneity in marginal productivity; screening of borrowers by lenders will depend more on heterogeneity that affects the total value of output.

The heterogeneity was introduced in section 3 as a vector of characteristics of the household $Z$. We focus on three dimensions of this heterogeneity: $z_{i}=\left(\eta_{i}, \theta_{i}, y_{i}\right) . \theta_{i}$ is an average productivity shifter that affects output but not the marginal product of the input, $\eta_{i}$ affects the marginal product, and $y_{i}$ is liquid wealth. The agricultural production function is $q_{i}=\tilde{f}\left(x_{i} ; \theta_{i}, \eta_{i}\right)+\varepsilon_{i}$, where $x_{i}$ is input use and $\varepsilon_{i}$ is the productivity shock that is revealed after inputs are applied. A convenient specification of the production function that satisfies these assumptions is

$$
q_{i}=\eta_{i} f\left(x_{i}\right)+\theta_{i}+\varepsilon_{i},
$$

\footnotetext{
${ }^{24}$ The MFI itself has little to no information about loan applicants, so it is almost impossible that the positive selection is due to the MFI's screening process. However, women must go through a community association which has joint liability for the loan - in order to get a contract with the MFI. It is therefore possible that the associations are screening out low-return farmers.
} 
where $f($.$) is increasing and concave. For shorthand, we refer to changes in \theta$ as changes in average productivity and to changes in $\eta$ as changes in marginal productivity. Each farmer $i$ is endowed with $\left(\theta_{i}, \eta_{i}, y_{i}\right)$. We consider a situation of symmetric information - both the farmer and the lender know the farmer's endowment before the loan is transacted, but neither knows the realization of $\varepsilon_{i}$. The lender provides loans normalized to size 1 , at an interest rate of $r$ (these parameters are set exogenously at a national level by Soro Yiriwaso). At the start of the farming season, $i$ chooses whether to borrow $B_{i} \in\{0,1\}$, and the lender chooses whether to lend $L_{i} \in\{0,1\}$. The loan is made if and only if $B_{i} L_{i}=1$. The farmer then applies inputs $x_{i}=y_{i}+B_{i} L_{i}$. This is the cash in advance constraint. We have assumed that the farmer has no alternative use for capital outside of agriculture. ${ }^{25}$

Output is produced: $q_{i}=f\left(x_{i} ; \theta_{i}, \eta_{i}\right)+\varepsilon_{i}$, and because of limited liability, the loan is repaid in full only if output is sufficiently high. ${ }^{26}$ The lender receives $\min \left\{(1+r) B_{i} L_{i}, \mathrm{q}_{i}\right\}-(1+\rho) B_{i} L_{i}$ and the farmer keeps $\max \left\{\mathrm{q}_{i}-(1+r) B_{i} L_{i}, 0\right\}$, where $\rho(<r)$ is the cost of funds to the lender. We assume that both farmer and the lender maximize expected profits.

As a consequence of limited liability, a borrowing farmer earns zero if $\varepsilon \leq \bar{\varepsilon}$, where

$$
\bar{\varepsilon} \equiv(1+r)-\eta_{i} f\left(y_{i}+1\right)-\theta_{i}
$$

The farmer will want to take a loan if and only if

$$
\left(\eta_{i} f\left(y_{i}+1\right)+\theta_{i}-(1+r)\right)(1-G(\bar{\varepsilon}))+\int_{\bar{\varepsilon}}^{\varepsilon^{H}} \varepsilon g(\varepsilon) d \varepsilon \geq \eta_{i} f\left(y_{i}\right)+\theta_{i} .
$$

\footnotetext{
${ }^{25}$ This assumption implies that $Q_{G} \equiv Q_{B}$, that is, that the farmer uses the grant in the same way he/she would use the loan. This unrealistic assumption can be generalized, at the cost of additional notation, while preserving the lessons we draw for patterns of selection in the following paragraphs.

26 We make assumptions to ensure that output is nonnegative. So $\left(\eta_{i}, \theta_{i}, y_{i}\right) \in \mathrm{P}=\left[\eta^{L}, \eta^{H}\right] \times\left[\theta^{L}, \theta^{H}\right] \times\left[y^{L}, y^{H}\right]$, with $\eta^{L} f\left(y^{L}\right)+\theta^{L} \equiv q^{L}>0$, and $\varepsilon_{i}$ is drawn from a continuous density $g(\varepsilon)$ with positive support on $\left[\varepsilon^{L}, \varepsilon^{H}\right]$, with $\varepsilon^{L} \geq-q^{L}$. The expected value of $\varepsilon$ is 0 .
} 
The set $B^{r e j}=\left\{(\eta, \theta, y) \mid\left(\eta_{i} f\left(y_{i}+1\right)+\theta_{i}-(1+r)\right)(1-G(\bar{\varepsilon}))+\int_{\bar{\varepsilon}}^{\varepsilon^{H}} \varepsilon g(\varepsilon) d \varepsilon<\eta_{i} f\left(y_{i}\right)+\theta_{i}\right\}$ defines the characteristics of farmers who would choose not to borrow. Define $\eta_{i}^{*}$ as the level of marginal productivity such that a loan that will not be defaulted on has an expected return just equal to the interest cost:

$$
\eta_{i}^{*}\left(f\left(y_{i}+1\right)-f\left(y_{i}\right)\right)=1+r .
$$

$\eta_{i}^{*}$ is independent of $\theta_{i}$ and is decreasing in $y_{i}{ }^{27}$ Second, define $\theta_{i}^{*} \equiv(1+r)-\eta_{i}^{*} f\left(y_{i}+1\right)-\varepsilon^{L}$. A borrowing farmer with an endowment $\left\{\theta_{i}^{*}, \eta_{i}^{*}, y_{i}\right\}$ never defaults, and (3) is satisfied with equality. For all $\eta_{i} \geq \eta_{i}^{*}$, a farmer with endowment $\left\{\theta_{i}^{*}, \eta_{i}, y_{i}\right\}$ chooses to borrow. Similarly, for all $\theta<\theta_{i}^{*}$, a farmer with endowment $\left\{\theta_{i}, \eta_{i}^{*}, y_{i}\right\}$ defaults with positive probability, and chooses to borrow because of the limited liability constraint. ${ }^{28}$ In figure 4 , we show the set of $(\eta, \theta)$ such that a farmer with a given $y_{i}$ would choose $B_{i}=1$. The solid curve labeled $B$ partitions the space such that farmers with endowments to the southeast of $B$ choose to borrow. ${ }^{29}$

The lender will choose to make the loan if expected profits are positive. So the lender is willing to lend to $i$ if and only if

$$
(1+r)(1-G(\bar{\varepsilon}))+\left(\eta_{i} f\left(y_{i}+1\right)+\theta_{i}\right) G(\bar{\varepsilon})+\int_{\varepsilon^{L}}^{\bar{\varepsilon}} \varepsilon g(\varepsilon) d \varepsilon \geq(1+\rho) .
$$

${ }^{27}$ We can say something about the magnitude of $\eta^{*}$, because the marginal cost of borrowing is on the order of $30 \%$. No household with expected returns under this magnitude will borrow to invest in agriculture unless the probability of default is positive.

28 From (3) $\left(\eta_{i}^{*} f\left(y_{i}+1\right)-(1+r)\right)=\eta_{i}^{*} f\left(y_{i}\right)$ and $\varepsilon^{L}=(1+r)-\eta_{i}^{*} f\left(y_{i}+1\right)-\theta_{i}^{*} \quad$. For $\theta<\theta_{i}^{*}$, $G\left((1+r)-\eta_{i}^{*} f\left(y_{i}+1\right)-\theta\right)>0$. Therefore, $E \max \left(\eta_{i}^{*} f\left(y_{i}+1\right)+\theta+\varepsilon_{i}-(1+r), 0\right)>\eta_{i}^{*} f\left(y_{i}\right)+\theta_{i}$.

${ }^{29} \mathrm{BB}$ is upward-sloping below $\left\{\theta_{i}^{*}, \eta_{i}^{*}, y_{i}\right\}$ by reasoning analogous to that in footnote28. If $\left\{\tilde{\theta}, \tilde{\eta}, y_{i}\right\}$ is a point on $\mathrm{BB}$ with a positive probability of default: then for all $\theta<\tilde{\theta}$, $G\left((1+r)-\tilde{\eta} f\left(y_{i}+1\right)-\tilde{\theta}\right)<G\left((1+r)-\tilde{\eta} f\left(y_{i}+1\right)-\theta\right)$ and the farmer endowed with $\left\{\theta, \tilde{\eta}, y_{i}\right\}$ strictly prefers to borrow. 
$L^{r e j}=\left\{(\eta, \theta, y) \mid(1+r)(1-G(\bar{\varepsilon}))+\left(\eta_{i} f\left(y_{i}+1\right)+\theta_{i}\right) G(\bar{\varepsilon})+\int_{\varepsilon^{L}}^{\bar{\varepsilon}} \varepsilon g(\varepsilon) d \varepsilon<(1+\rho)\right\}$ defines the set of borrower characteristics such that the lender would not be willing to lend to the borrower with those characteristics. Equation (5) is satisfied for farmer $i$ with endowment $\left\{\theta_{i}^{*}, \eta_{i}^{*}, y_{i}\right\}$, because $r>\rho$. in figure 4 , the dashed curve labeled $L$ partitions the space such that the lender is willing to make a loan to farmers with endowments to the northeast of $L$; for a given $y_{i}$, the set $L^{r e j}$ is the area to the southwest of $L$.

We can now consider the consequences of self-selection versus lender screening for the observed distribution of profits. In the control villages, where grants were given to a random sample of the population, we have

$$
\begin{aligned}
\Pi_{i}^{N G} & =\eta_{i} f\left(y_{i}\right)+\theta_{i}+\varepsilon_{i}-y_{i} \\
\Pi_{j}^{G r a n t} & =\eta_{j} f\left(y_{j}+1\right)+\theta_{j}+\varepsilon_{j}-y_{j}-1
\end{aligned}
$$

for farmers $i$ and $j$ randomly selected into the no grant and grant treatment groups, respectively. Let $h(\eta, \theta, y)$ denote the joint density of $\eta, \theta$ and $y$ in the rural population of our study area, then given our randomization, the distributions of $\Pi_{j}^{\text {Grant }}$ and $\Pi_{i}^{N G}$ simply reflect draws from the full density $h($ ). The left panel of figure 5 depicts these distributions; as can be anticipated from our preceding results, the distribution of $\Pi_{j}^{\text {Grant }}$ lies to the right of that of $\Pi_{i}^{N G}$ over virtually the whole range.

In the loan villages, grants were given to a random sample of non-borrowers. Suppose that selection into borrowing is being driven by the simultaneous operation of both borrower side self-selection and by lender-side screening; that is, that the selection is driven jointly by equations (3) and (5). In this case, the joint density of $\eta, \theta$ and $Y$ in the population of nonborrowers is the truncated probability distribution

$$
h^{r e j}(\eta, \theta, y)=\frac{h(\eta, \theta, y)}{\operatorname{prob}\left((\eta, \theta, y) \in\left\{L^{r e j} \cup B^{r e j}\right\}\right)}
$$

with support $(\eta, \theta, y) \in\left\{L^{r e j} \cup B^{r e j}\right\}$. As can be seen in figure 4 , the endowments of the approximately 80 percent of the population who do not borrow differ from the overall population in two ways. First, because of lender screening, the distribution of endowments in the selected population of non-borrowers has greater weight on low values of average 
productivity $\theta$. Second, because of borrower self-selection, the selected population contains a higher proportion of farmers with low marginal productivity. Put differently, self-selection implies that among non-borrowers with high average productivity, a disproportionately large share will have low marginal productivity. And lender-selection implies that among nonborrowers with high marginal productivity, a disproportionate share will have low average productivity.

The right panel of figure 5 depicts the distributions of $\Pi_{j}^{G r a n t}$ and $\Pi_{i}^{N G}$ for the randomly chosen grant recipients and non-grant recipients among the population of non-borrowers in the loan villages. There are two distinctive feature of this graph. First is the presence of a significant fraction of non-borrowers with relatively high profits (>\$500), but approximately zero marginal return from the grant. Second is the presence of a significant fraction of non-borrowers with high marginal productivity but very low average productivity. These features correspond to the two mechanisms of lender screening and borrower self-selection when the realizations of $\Pi_{j}^{\text {Grant }}$ and $\Pi_{i}^{N G}$ are determined jointly by equations (3) and (6), so that non-borrower endowments are drawn from $h^{r e j}(\eta, \theta, y)$.

Column (1) of Table 5 echoes this finding. We include additional interaction terms to look at heterogeneity between loan and no-loan villages in the returns to the grants by baseline profits. Column (1) shows that Grant * Baseline profits *Loan village * Year 1 is significantly correlated with profits, and the inclusion of these additional interaction terms erodes the primary selection effect on Grant * Loan village * year 1 . Had the effect been driven by supplyside screening, we would see the grant * baseline profits * year 1 capture the selection effect (because the supply-side screeners, whether the lender or the peers, would choose only the high profit level, i.e., high baseline profits, farmers as clients). Instead, after controlling for that, we observe selection occurring on marginal profits. Thus this supports the conclusion that at least part of the selection effect is via self-selection.

\section{Impact of the loans}

We also show our estimates of the intent-to-treat (ITT) effects of being offered an agricultural loan on the same set of outcomes already discussed in section 3. In this analysis, we exclude all grant recipients, from both loan and ineligible villages. Panel B of Tables 2 and 3 show the results of the loan intent-to-treat analysis. We use the following specification:

$$
Y_{i j t}=\alpha+\beta_{1} \operatorname{loan}_{j} \cdot I\{t=2011\}+\beta_{2} \operatorname{loan}_{j} \cdot I\{t=2012\}+X_{i j t} \pi+\theta_{j}+\varepsilon_{i j t}
$$


where $(X)$ which include the baseline value of the dependent variable $y_{0}$, cercle fixed effects, and the village stratification controls described in section 2.3 and listed in the notes of the table Table 2 . The specification uses probability weights to account for the sampling strategy, which depends on take-up in the loan villages.

Panel B of Tables 2 and 3 show the ITT estimates. In Table 2, we observe an increase in input expenditures on family labor days $(8.7, \mathrm{se}=4.8)$, in fertilizer expenses $(\$ 10.35$, se=5.09) and other chemical expenses including insecticides and herbicides $(\$ 5.08, \mathrm{se}=2.76)$ in villages offered loans. Land cultivated also increases but is only at the margin of statistical significance (0.094 ha, se=0.058). The value of the harvest also increases by $\$ 32$ (se=19), but we do not measure a statistically significant increase in profits $(\$ 17, \mathrm{se}=15.8)$. Panel B of Table 3 shows an increase in the value of livestock $(\$ 168, \mathrm{se}=89)$ in Column $(2)$ and a reduction in medical expenses $(-\$ 4.78$, se=1.62) in Column (10). We do not detect an impact on the other outcomes, including food and non-food consumption, whether the household has a small business, nor educational expenses. ${ }^{30}$

These results on impact of loans stand in stark contrast both to the recent literature on the impact of entrepreneurially-focused credit (see Angelucci, Karlan, and Zinman 2015; Attanasio et al. 2015; Augsburg et al. 2015; Banerjee et al. 2015; Crepon et al. 2015; Karlan and Zinman 2011; Tarozzi, Desai, and Johnson 2015), and an earlier agricultural lending literature that documented consistent institutional failures, typically with high default rates (Adams, Graham, and Von Pischke 1984; Adams 1971). The institutional results are also promising: the perfect repayment, and the retention to the following year $(50 \%)$ is on par with typical client retention rates for sustainable, entrepreneurially-focused microcredit operations. The self-selection results do highlight, however, that estimating the treatment-on-the-treated (TOT) results would be inappropriate, since those who chose not to borrow have considerably lower returns to capital than those who choose to borrow.

\section{Conclusion}

Capital constraints are a binding constraint for at least some farmers in Southern Mali, and we find that agricultural lending with balloon payments (i.e., with cash flows matched to those of the intended productive activity) is a plausible way to increase investments in agriculture. This

\footnotetext{
${ }^{30}$ Appendix Table A4 further shows no detectable effect on business profits, women's decision-making power within the household, women's involvement in community decisions, nor on women's social capital. This is similar to the existing evaluations of microcredit (Attanasio et al. 2015; Augsburg et al. 2015; Banerjee et al. 2015; Crepon et al. 2015; except Angelucci, Karlan, and Zinman 2015). Soro Yiriwaso did not have any explicit component of the program emphasizing women's empowerment.
} 
is an important policy lesson since the majority of microcredit has focused on small enterprise lending, and the typical microcredit loan contract - where clients must start repayment after a few weeks - is simply ill-suited for agriculture. Field et. al. (2013) find similar results merely from delaying the onset of high frequency repayment, within the context of microenterprise. In Mali, for example, Soro Yiriwaso is the only microcredit organization with a product specially designed for agriculture, despite the fact that the vast majority of households in rural Mali depend on agriculture for a sizeable part of their livelihood.

Key to our main purpose, we find that the returns to capital in cultivation are heterogeneous and that higher marginal-return farmers self-select into borrowing more so than low marginalreturn farmers. This has important implications for models of credit markets. In particular, our results provide rigorous empirical evidence for optimal selection into contracts, which is embedded in models like Evans and Jovanovic (1989), Buera (2009) and Moll (2013) but which has lacked clear empirical evidence. Our results also highlight the need to incorporate heterogeneity of returns in such models, as recognized by Kaboski and Townsend (2011).

These results are also important for policy, for example the targeting of social programs. Cash transfer programs are often means-tested and recent work suggests that both community targeting, where community members rank-order households to identify the poor, and ordeal mechanisms can be an effective way of generating screening on wealth/income in developing countries (Alatas et al. 2012; Alatas et al. 2013). Price is the screening mechanism we look at here with agricultural loans. The literature on health products in developing countries finds mixed evidence on whether positive prices or cost sharing creates a screening effect on usage. ${ }^{31}$ Cohen, Dupas, and Schaner (2012) highlight the tradeoff between access and targeting through pricing of health products when the benefits are heterogeneous across households, as in their case with anti-malarial medication. Higher subsidies lead to higher access for households with malaria but poor targeting: among adults, about half of the subsidized medications went to people who did not have malaria. In a different setting, Jack (2013) finds that a willingness to accept mechanism can induce self-selection among landholders in Malawi, leading to improved project success for tree planting. We find that in agriculture, the lending process is a mechanism that generates positive self-selection so farmers who benefit the most from relaxing capital constraints are more likely to choose to borrow.

\footnotetext{
${ }^{31}$ Cohen and Dupas (2010) and Tarozzi et al (2013) find no evidence households given bednets for free are less likely to use them. Ashraf, Berry, and Shapiro (2010), by contrast, find evidence that households who paid higher prices were more likely to use a water purification product. Tarozzi et al does find, though, that households who have malaria at baseline are more likely to take out microloans for bednets than those without malaria. (Dupas 2013) provides a summary of the literature.
} 


\section{References}

Adams, Dale W. 1971. "Agricultural Credit in Latin America: A Critical Review of External Funding Policy." American Journal of Agricultural Economics 53 (2): 163-72. doi:10.2307/1237428.

Adams, Dale W., Douglas H. Graham, and J. D. Von Pischke, eds. 1984. Undermining Rural Development with Cheap Credit. Westview Special Studies in Social, Political, and Economic Development. Boulder: Westview Press.

Alatas, Vivi, Abhijit Banerjee, Rema Hanna, Benjamin A Olken, and Julia Tobias. 2012. "Targeting the Poor: Evidence from a Field Experiment in Indonesia." The American Economic Review 102 (4): 1206-40.

Alatas, Vivi, Abhijit Banerjee, Rema Hanna, Olken, Benjamin, Ririn Purnamasari, and Matthew Wai_Poi. 2013. "Self-Targeting: Evidence from a Field Experiment in Indonesia."

Angelucci, Manuela, Dean Karlan, and Jonathan Zinman. 2015. “Microcredit Impacts: Evidence from a Randomized Microcredit Program Placement Experiment by Compartamos Banco." American Economic Journal: Applied Economics.

Armendariz de Aghion, Beatriz, and Jonathan Morduch. 2010. The Economics of Microfinance. 2nd ed. Cambridge, MA: MIT Press.

Ashraf, Nava, James Berry, and Jesse M Shapiro. 2010. "Can Higher Prices Stimulate Product Use? Evidence from a Field Experiment in Zambia." American Economic Review 100 (5): 2383-2413. doi:10.1257/aer.100.5.2383.

Attanasio, Augsburg, Britta Augsburg, Ralph de Haas, Fitz Fitzsimons, and Heike Harmgart. 2015. "Group Lending or Individual Lending? Evidence from a Randomised Field Experiment in Mongolia." American Economic Journal: Applied Economics 136.

Augsburg, Britta, Ralph de Haas, Heike Harmgart, and Costas Meghir. 2015. "Microfinance at the Margin: Experimental Evidence from Bosnia and Herzegovina." American Economic Journal: Applied Economics.

Banerjee, Abhijit, and Esther Duflo. 2012. "Do Firms Want to Borrow More? Testing Credit Constraints Using a Directed Lending Program." M.I.T. Working Paper.

Banerjee, Abhijit, Esther Duflo, Rachel Glennerster, and Cynthia Kinnan. 2015. "The Miracle of Microfinance? Evidence from a Randomized Evaluation." American Economic Journal: Applied Economics.

Banerjee, Abhijit, Dean Karlan, and Jonathan Zinman. 2015. "Six Randomized Evaluations of Microcredit: Introduction and Further Steps." American Economic Journal: Applied Economics 7 (1): 1-21. doi:10.1257/app.20140287.

Bank, World. 2000. "Spurring Agricultural and Rural Development." In , 170-207. Can Africa Claim the 21st Century? Washington, DC.

Beaman, Lori, Dean Karlan, Bram Thuysbaert, and Christopher Udry. 2013. "Profitability of Fertilizer: Experimental Evidence from Female Rice Farmers in Mali." American Economic Review Papers \& Proceedings, May. 
Bruhn, Miriam, and David McKenzie. 2009. "In Pursuit of Balance: Randomization in Practice in Development Field Experiments." American Economic Journal: Applied Economics 1 (4): 200-232.

Buera, Francisco J. 2009. "A Dynamic Model of Entrepreneurship with Borrowing Constraints: Theory and Evidence." Annals of Finance 5 (3-4): 443-64.

Cohen, Jessica, and Pascaline Dupas. 2010. "Free Distribution or Cost-Sharing? Evidence from a Randomized Malaria Prevention Experiment "." Quarterly Journal of Economics 125 (1): 1-45. doi:10.1162/qjec.2010.125.1.1.

Cohen, Jessica, Pascaline Dupas, and Simone G Schaner. 2012. "Price Subsidies, Diagnostic Tests, and Targeting of Malaria Treatment: Evidence from a Randomized Controlled Trial."

Crepon, Bruno, Florencia Devoto, Esther Duflo, and William Pariente. 2015. "Impact of Microcredit in Rural Areas of Morocco: Evidence from a Randomized Evaluation." American Economic Journal: Applied Economics.

De Mel, Suresh, David McKenzie, and Christopher Woodruff. 2008. "Returns to Capital in Microenterprises: Evidence from a Field Experiment." Quarterly Journal of Economics 123 (4): 1329-72.

De Quidt, Jonathan, Thiemo Fetzer, and Maitreesh Ghatak. 2012. "Group Lending Without Joint Liability." London School of Economics Working Paper.

Druilhe, Z., and J. Barreiro-Huré. 2012. "Fertilizer Subsidies in Sub-Saharan Africa." FAO ESA Working Paper No 12-04.

Duflo, Esther, Michael Kremer, and Jonathan Robinson. 2008. "How High Are Rates of Return to Fertilizer? Evidence from Field Experiments in Kenya." American Economic Review 98 (2): 482-88.

- - . 2011. "Nudging Farmers to Use Fertilizer: Theory and Experimental Evidence from Kenya." American Economic Review 101 (6): 2350-90. doi:10.1257/aer.101.6.2350.

Dupas, Pascaline. 2013. "Short-Run Subsidies and Long-Run Adoption of New Health Products: Experimental Evidence from Kenya." Econometrica forthcoming.

Evans, David S, and Boyan Jovanovic. 1989. "An Estimated Model of Entrepreneurial Choice under Liquidity Constraints." The Journal of Political Economy 97 (4): 808.

Evenson, R.E., and D. Gollin. 2003. "Assessing the Impact of the Green Revolution, 1960 to 2000." Science 300 (758): 758-62.

Field, Erica, Rohini Pande, John Papp, and Natalia Rigol. 2013. "Does the Classic Microfinance Model Discourage Entrepreneurship Among the Poor? Experimental Evidence from India." American Economic Review 103 (6): 2196-2226. doi:10.1257/aer.103.6.2196.

Giné, Xavier, and Dean S. Karlan. 2014. "Group versus Individual Liability: Short and Long Term Evidence from Philippine Microcredit Lending Groups." Journal of Development Economics 107 (March): 65-83. doi:10.1016/j.jdeveco.2013.11.003.

Jack, B Kelsey. 2013. "Private Information and the Allocation of Land Use Subsidies in Malawi." American Economic Journal: Applied Economics 5 (3): 113-35.

Kaboski, Joseph P, and Robert M Townsend. 2011. "A Structural Evaluation of a Large-Scale Quasi-Experimental Microfinance Initiative." Econometrica 79 (5): 1357-1406. 
Karlan, Dean, and Jonathan Morduch. 2009. "Access to Finance." In Handbook of Development Economics, edited by Dani Rodrick and M. R. Rosenzweig. Vol. 5. Elsevier.

Karlan, Dean, Isaac Osei-Akoto, Robert Darko Osei, and Christopher R. Udry. 2013. "Agricultural Decisions after Relaxing Credit and Risk Constraints." Quarterly Journal of Economics, Forthcoming. doi:10.2139/ssrn.2169548.

Karlan, Dean, and Jonathan Zinman. 2011. "Microcredit in Theory and Practice: Using Randomized Credit Scoring for Impact Evaluation." Science 332 (6035): 1278-84.

Kazianga, Harounan, and Christopher Udry. 2006. "Consumption Smoothing? Livestock, Insurance and Drought in Rural Burkina Faso." Journal of Development Economics 79 (2): 413-46. doi:10.1016/j.jdeveco.2006.01.011.

Kremer, Michael, and Edward A Miguel. 2004. "The Illusion of Sustainability." Center for International and Development Economics Research Paper C05-141.

Moll, Benjamin. Forthcoming. "Productivity Losses from Financial Frictions: Can Self-Financing Undo Capital Misallocation?" American Economic Review

Suri, Tavneet. 2011. "Selection and Comparative Advantage in Technology Adoption." Econometrica 79 (1): 159-209. doi:10.3982/ECTA7749.

Tarozzi, Alessandro, Jaikishan Desai, and Kristin Johnson. 2015. "On the Impact of Microcredit: Evidence from a Randomized Intervention in Rural Ethiopia." American Economic Journal: Applied Economics.

Tarozzi, A., Mahajan, A., Blackburn, B., Kopf, D., Krishnan, L., \& Yoong, J. 2013. “Micro-Loans, Bednets and Malaria: Evidence from a Randomized Controlled Trial." American Economic Review Forthcoming.

Udry, C., and S. Anagol. 2006. "The Return to Capital in Ghana." The American Economic Review 96 (2): 388-93. 


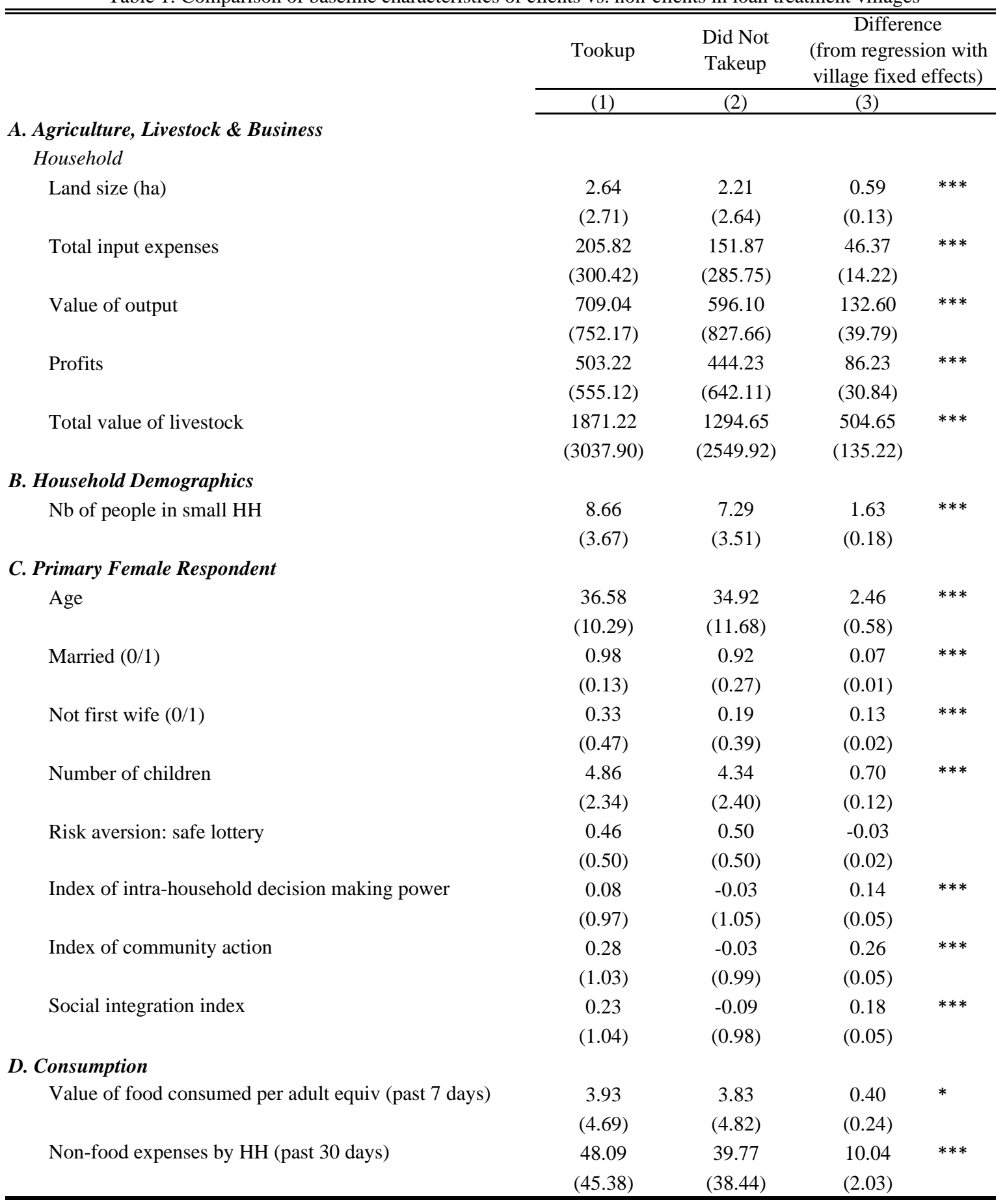

Notes

1 The household decision-making index includes questions on how much influence she has on decisions in the following domains: food for the household, children's schooling expenses, their own health, her own travel within the village, and economic activities such as fertilizer purchases and raw materials for small business activities. The community action index includes questions on: how frequently she speaks with different village leaders, and different types of participation in village meetings and activities. The social capital index includes questions about 7 other randomly selected community members from our sample and whether the respondent knows the person, are in the same organization, would engage in informal risk sharing and transfers with the person, and topics of their discussions (if any). All three of these variables are indices, normalized by the no-grant households in loanunavailable villages.

2 Clients are defined by households who took out a loan in the 2010 agricultural season. 
Table 2: Agriculture

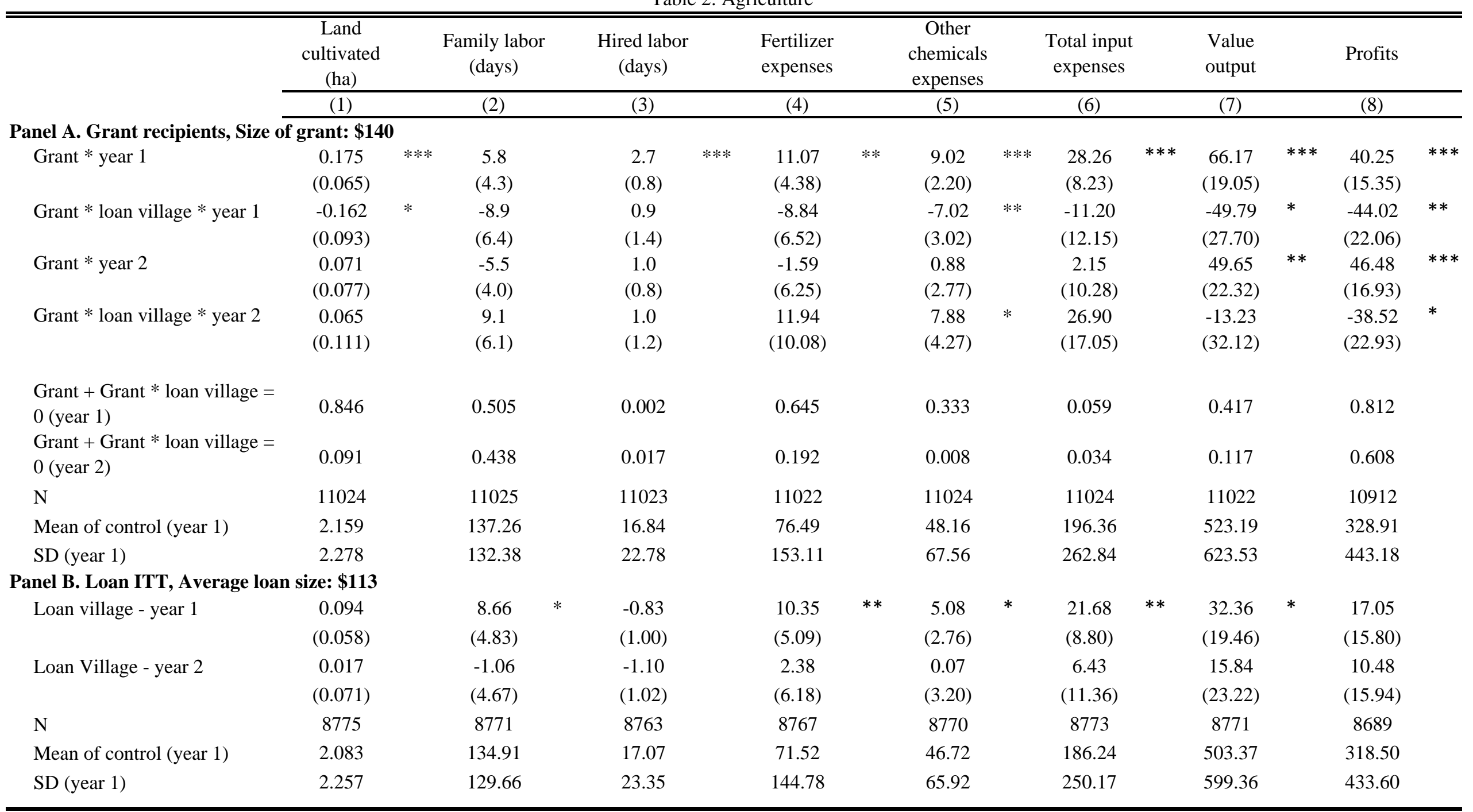

Notes

1 Rows showing Grant + Grant * loan village $=0$ (year 1 ) shows the p value of the test of whether the total effect of grants in loan villages is statistically different from zero.

2 Total input expenses includes fertilizer, manuring, herbicide, insecticide, farming equipment and hired labor but excludes the value of family labor.

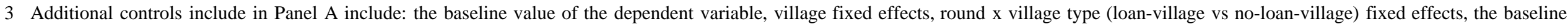

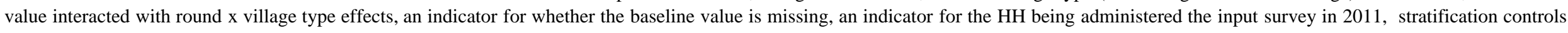

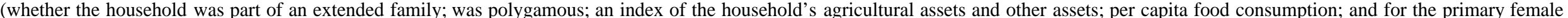

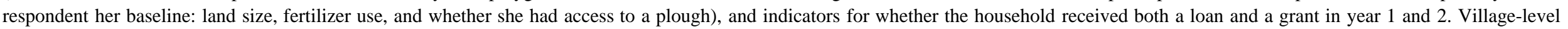
stratification controls are not included since there are village fixed effects.

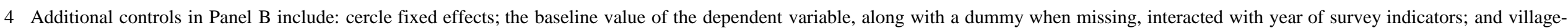

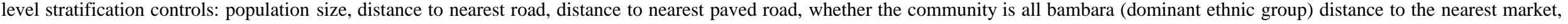

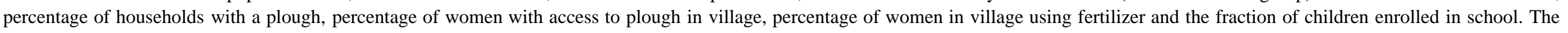
specification uses probability weights to reflect sampling design.

5 Standard errors are in paranetheses and clustered at the village level in all specifications. 
Table 3: Other Outcomes

\begin{tabular}{|c|c|c|c|c|c|c|c|c|c|c|c|c|c|c|c|c|}
\hline & $\begin{array}{l}\text { Own any } \\
\text { livestock }\end{array}$ & & $\begin{array}{l}\text { Total value } \\
\text { of livestock }\end{array}$ & & $\begin{array}{l}\text { HH has a } \\
\text { business }\end{array}$ & & $\begin{array}{c}\text { Food } \\
\text { consumption } \\
\text { EQ (past } 7 \\
\text { days) } \\
\end{array}$ & & $\begin{array}{l}\text { Monthly } \\
\text { non-food } \\
\text { exp }\end{array}$ & & $\begin{array}{c}\text { HH has any } \\
\text { financial } \\
\text { savings }\end{array}$ & $\begin{array}{l}\text { Primary is } \\
\text { member of } \\
\text { ROSCA }\end{array}$ & & $\begin{array}{c}\text { Educ } \\
\text { expenses }\end{array}$ & $\begin{array}{c}\text { Medical } \\
\text { expenses }\end{array}$ & \\
\hline & $(1)$ & & $(2)$ & & (3) & & $(4)$ & & (5) & & (6) & $(7)$ & & $(8)$ & (9) & \\
\hline \multicolumn{17}{|c|}{ Panel A. Grant recipients, Size of grant: $\$ 140$} \\
\hline Grant * year 1 & $\begin{array}{c}0.114 \\
(0.014)\end{array}$ & $* * *$ & $\begin{array}{l}158.06 \\
(72.15)\end{array}$ & ** & $\begin{array}{c}0.038 \\
(0.015)\end{array}$ & $* *$ & $\begin{array}{c}0.38 \\
(0.11)\end{array}$ & $* * *$ & $\begin{array}{c}2.95 \\
(1.40)\end{array}$ & $* *$ & $\begin{array}{c}0.024 \\
(0.016)\end{array}$ & $\begin{array}{c}0.017 \\
(0.015)\end{array}$ & & $\begin{array}{c}2.24 \\
(3.03)\end{array}$ & $\begin{array}{l}-2.54 \\
(1.85)\end{array}$ & \\
\hline Grant * loan village * year 1 & $\begin{array}{c}-0.046 \\
(0.022)\end{array}$ & $* *$ & $\begin{array}{c}-42.31 \\
(109.33)\end{array}$ & & $\begin{array}{c}-0.007 \\
(0.022)\end{array}$ & & $\begin{array}{l}-0.08 \\
(0.17)\end{array}$ & & $\begin{array}{c}1.02 \\
(2.03)\end{array}$ & & $\begin{array}{c}0.023 \\
(0.029)\end{array}$ & $\begin{array}{l}-0.010 \\
(0.023)\end{array}$ & & $\begin{array}{l}-1.72 \\
(5.27)\end{array}$ & $\begin{array}{c}4.37 \\
(2.52)\end{array}$ & * \\
\hline Grant * year 2 & $\begin{array}{c}0.092 \\
(0.015)\end{array}$ & $* * *$ & $\begin{array}{c}270.05 \\
(132.50)\end{array}$ & $* *$ & $\begin{array}{c}0.030 \\
(0.013)\end{array}$ & $* *$ & $\begin{array}{c}0.05 \\
(0.17)\end{array}$ & & $\begin{array}{c}3.89 \\
(2.12)\end{array}$ & * & $\begin{array}{c}0.035 \\
(0.019)\end{array}$ & $\begin{array}{c}0.039 \\
(0.018)\end{array}$ & $* *$ & $\begin{array}{c}0.41 \\
(3.64)\end{array}$ & $\begin{array}{l}-0.76 \\
(1.80)\end{array}$ & \\
\hline Grant * loan village * year 2 & $\begin{array}{c}0.000 \\
(0.023)\end{array}$ & & $\begin{array}{c}-275.21 \\
(177.89)\end{array}$ & & $\begin{array}{l}-0.025 \\
(0.020)\end{array}$ & & $\begin{array}{c}0.35 \\
(0.23)\end{array}$ & & $\begin{array}{l}-1.54 \\
(2.76)\end{array}$ & & $\begin{array}{c}0.034 \\
(0.026)\end{array}$ & $\begin{array}{c}-0.016 \\
(0.025)\end{array}$ & & $\begin{array}{c}0.07 \\
(5.00)\end{array}$ & $\begin{array}{c}1.02 \\
(2.72)\end{array}$ & \\
\hline $\begin{array}{l}\text { Grant }+ \text { Grant } * \text { loan village }=0 \\
\text { (year } 1)\end{array}$ & 0.000 & & 0.161 & & 0.065 & & 0.015 & & 0.007 & & 0.053 & 0.687 & & 0.903 & 0.284 & \\
\hline $\begin{array}{l}\text { Grant }+ \text { Grant } * \text { loan village }=0 \\
\text { (year } 2 \text { ) }\end{array}$ & 0.000 & & 0.965 & & 0.750 & & 0.015 & & 0.182 & & 0.000 & 0.180 & & 0.887 & 0.900 & \\
\hline $\mathrm{N}$ & 10846 & & 10793 & & 10848 & & 10748 & & 10434 & & 10727 & 10727 & & 7500 & 10752 & \\
\hline Mean of control (year 1) & 0.780 & & 1237.69 & & 0.828 & & 3.25 & & 43.56 & & 0.636 & 0.250 & & 71.49 & 31.56 & \\
\hline SD (year 1) & 0.414 & & 2096.50 & & 0.377 & & 3.26 & & 36.89 & & 0.481 & 0.433 & & 81.73 & 44.79 & \\
\hline \multicolumn{17}{|c|}{ Panel B. Loan ITT, Average loan size: \$113 } \\
\hline Loan village - year 1 & $\begin{array}{c}0.010 \\
(0.014)\end{array}$ & & $\begin{array}{l}168.08 \\
(88.53)\end{array}$ & * & $\begin{array}{l}-0.007 \\
(0.023)\end{array}$ & & $\begin{array}{c}0.10 \\
(0.13)\end{array}$ & & $\begin{array}{c}0.20 \\
(2.11)\end{array}$ & & $\begin{array}{c}0.019 \\
(0.024)\end{array}$ & $\begin{array}{l}-0.011 \\
(0.024)\end{array}$ & & $\begin{array}{c}4.35 \\
(3.95)\end{array}$ & $\begin{array}{l}-4.78 \\
(1.62)\end{array}$ & $* * *$ \\
\hline Loan Village - year 2 & $\begin{array}{l}-0.008 \\
(0.017)\end{array}$ & & $\begin{array}{c}48.33 \\
(111.44)\end{array}$ & & $\begin{array}{c}0.002 \\
(0.015)\end{array}$ & & $\begin{array}{c}0.07 \\
(0.17)\end{array}$ & & $\begin{array}{l}-0.45 \\
(2.49)\end{array}$ & & $\begin{array}{c}0.004 \\
(0.027)\end{array}$ & $\begin{array}{l}-0.016 \\
(0.026)\end{array}$ & & $\begin{array}{c}3.36 \\
(3.47)\end{array}$ & $\begin{array}{l}-0.78 \\
(1.81)\end{array}$ & \\
\hline $\mathrm{N}$ & 8634 & & 8634 & & 8634 & & 8566 & & 8291 & & 8533 & 8533 & & 6050 & 8539 & \\
\hline Mean of control (year 1) & 0.777 & & 1341.16 & & 0.833 & & 3.19 & & 44.28 & & 0.635 & 0.263 & & 69.87 & 33.26 & \\
\hline SD (year 1) & 0.417 & & 2479.04 & & 0.373 & & 3.20 & & 38.27 & & 0.482 & 0.440 & & 81.20 & 44.98 & \\
\hline
\end{tabular}

Notes

1 Rows showing Grant + Grant * loan village $=0$ (year 1 ) shows the p value of the test of whether the total effect of grants in loan villages is statistically different from zero.

2 See the notes of Table 2.1 for details on specifications. 


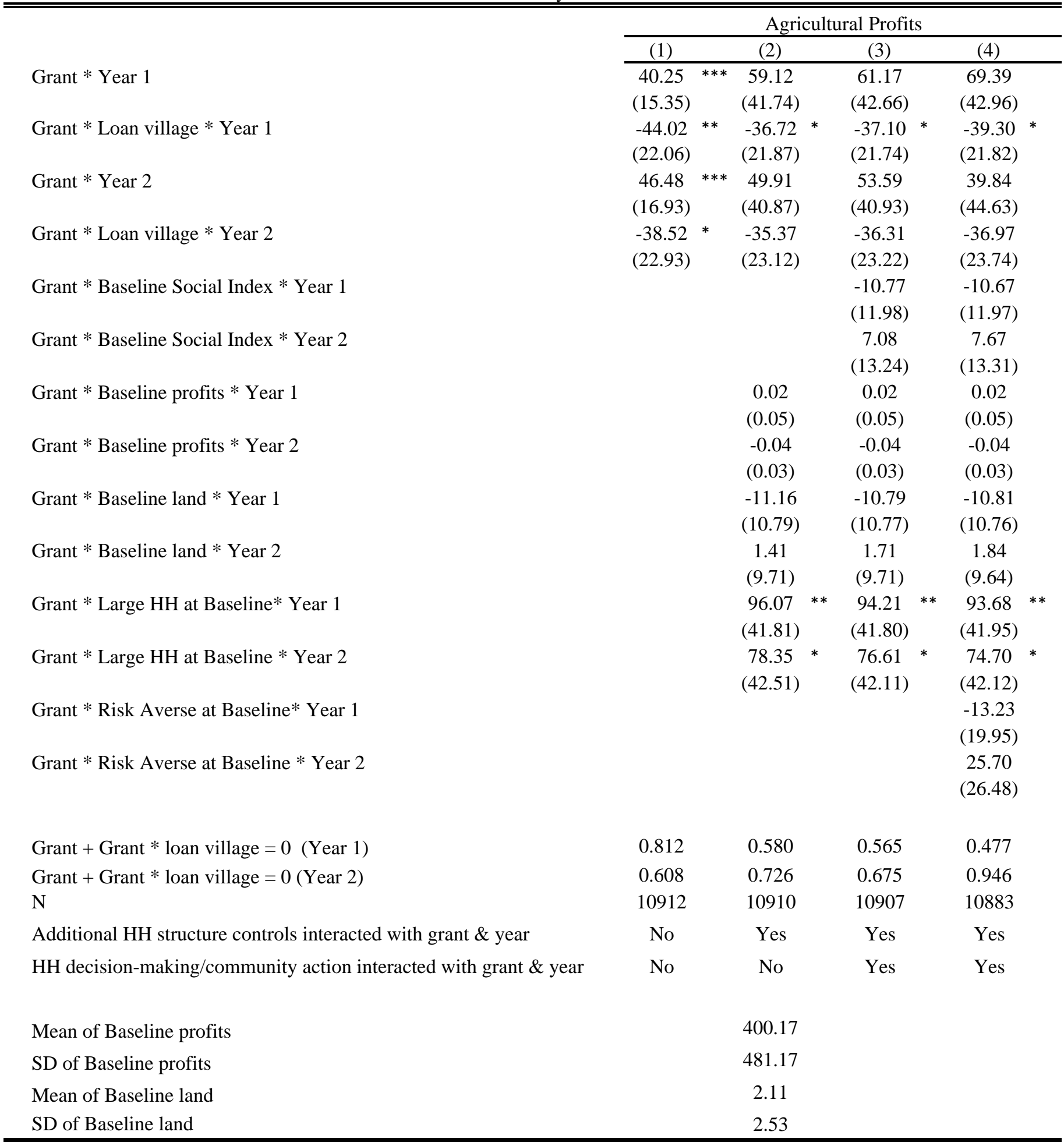

Notes

1 Rows showing Grant + Grant * loan village $=0$ (Year 1$)$ shows the p value of the test of whether the total effect of grants in loan villages is statistically different from zero.

2 See the notes of Table 2.1 for details on specification.

3 Risk averse is an indicator for the household choosing the safe lottery, which about half the sample seleted. Large household is 6 or more adults in the household.

4 Other household structure controls include: an indicator for the presence of an extended family and the number of children in the household. 


\section{Grant * Year 1}

Grant * Loan village * Year 1

Grant * Year 2

Grant * Loan village * Year 2

Grant * Baseline Social Index * Year 1

Grant * Baseline Social Index * Loan village * Year 1

Grant * Baseline Social Index * Year 2

Grant * Baseline Social Index * Loan village * Year 2

Grant * Baseline profits * Year 1

Grant * Baseline profits * Loan village * Year 1

Grant * Baseline profits * Year 2

Grant * Baseline profits * Loan Village * Year 2

Grant * Baseline land * Year 1

Grant * Baseline land * Year 2

Grant * Large HH at Baseline* Year 1

Grant * Large HH at Baseline * Year 2

Grant * Risk Averse at Baseline* Year 1

Grant * Risk Averse at Baseline * Year 2

Grant + Grant $*$ loan village $=0($ Year 1$)$

Grant + Grant $*$ loan village $=0($ Year 2$)$

$\mathrm{N}$

Additional HH structure controls interacted with grant \& year

HH decision-making/community action interacted with grant \& year

Mean of Baseline profits

SD of Baseline profits

Mean of Baseline land

SD of Baseline land

\begin{tabular}{|c|c|c|c|c|c|c|c|c|c|}
\hline \multicolumn{10}{|c|}{ Agricultural Profits } \\
\hline$(1)$ & & $(2)$ & & (3) & & $(4)$ & & (5) & \\
\hline 39.80 & $* *$ & 56.24 & & 60.68 & & 68.92 & & 43.37 & \\
\hline (15.35) & & $(42.41)$ & & (42.61) & & $(42.91)$ & & $(46.61)$ & \\
\hline-42.82 & $*$ & -36.04 & & -35.91 & & -38.12 & $*$ & 18.43 & \\
\hline (22.59) & & $(22.44)$ & & $(22.24)$ & & $(22.32)$ & & $(29.45)$ & \\
\hline 47.14 & $* * *$ & 50.74 & & 53.27 & & 38.65 & & 32.91 & \\
\hline (16.89) & & (41.01) & & $(40.71)$ & & $(44.44)$ & & (44.98) & \\
\hline-39.90 & $*$ & -36.98 & & -37.74 & & -38.30 & & -28.93 & \\
\hline (23.01) & & (23.26) & & (23.20) & & $(23.70)$ & & (23.77) & \\
\hline-15.36 & & -14.96 & & -16.93 & & -16.74 & & -17.18 & \\
\hline (14.59) & & (14.76) & & (15.08) & & $(15.00)$ & & (14.96) & \\
\hline 16.43 & & 11.80 & & 13.76 & & 13.47 & & 14.52 & \\
\hline (22.02) & & (21.69) & & $(21.87)$ & & $(21.81)$ & & $(21.74)$ & \\
\hline 16.82 & & 15.64 & & 18.22 & & 18.99 & & 18.66 & \\
\hline (13.54) & & (13.52) & & $(14.60)$ & & $(14.68)$ & & (14.68) & \\
\hline-30.04 & & -31.52 & & -28.90 & & -29.32 & & -28.62 & \\
\hline \multirow[t]{17}{*}{ (21.97) } & & (22.20) & & (22.36) & & (22.38) & & (22.49) & \\
\hline & & 0.02 & & 0.02 & & 0.02 & & 0.05 & \\
\hline & & (0.05) & & $(0.05)$ & & (0.05) & & $(0.07)$ & \\
\hline & & & & & & & & $\begin{array}{l}-0.14 \\
(0.07)\end{array}$ & $* *$ \\
\hline & & -0.04 & & -0.04 & & -0.04 & & -0.03 & \\
\hline & & (0.03) & & $(0.03)$ & & $(0.03)$ & & $(0.04)$ & \\
\hline & & & & & & & & $\begin{array}{l}-0.02 \\
(0.05)\end{array}$ & \\
\hline & & -10.88 & & -10.79 & & -10.81 & & -3.90 & \\
\hline & & (10.80) & & (10.78) & & (10.76) & & (10.59) & \\
\hline & & 1.08 & & 1.49 & & 1.62 & & 2.37 & \\
\hline & & $(9.76)$ & & (9.71) & & (9.64) & & (10.11) & \\
\hline & & $\begin{array}{c}96.55 \\
(41.78)\end{array}$ & ** & $\begin{array}{c}93.83 \\
(41.78)\end{array}$ & $* *$ & $\begin{array}{c}93.30 \\
(41.94)\end{array}$ & $* *$ & $\begin{array}{c}90.63 \\
(42.55)\end{array}$ & $* *$ \\
\hline & & $\begin{array}{c}78.64 \\
(42.46)\end{array}$ & * & $\begin{array}{c}76.78 \\
(42.08)\end{array}$ & * & $\begin{array}{c}74.76 \\
(42.08)\end{array}$ & $*$ & $\begin{array}{c}73.45 \\
(41.92)\end{array}$ & $*$ \\
\hline & & & & & & -13.23 & & -11.44 & \\
\hline & & & & & & (20.11) & & (19.94) & \\
\hline & & & & & & 26.95 & & 27.03 & \\
\hline & & & & & & (26.55) & & (26.54) & \\
\hline 0.856 & & 0.627 & & 0.555 & & 0.468 & & 0.146 & \\
\hline 0.644 & & 0.744 & & 0.706 & & 0.993 & & 0.925 & \\
\hline 10910 & & 10908 & & 10907 & & 10883 & & 10883 & \\
\hline No & & Yes & & Yes & & Yes & & Yes & \\
\hline \multirow[t]{5}{*}{ No } & & No & & Yes & & Yes & & Yes & \\
\hline & & 400.17 & & & & & & & \\
\hline & & 481.17 & & & & & & & \\
\hline & & 2.11 & & & & & & & \\
\hline & & 2.53 & & & & & & & \\
\hline
\end{tabular}

Notes

1 Rows showing Grant + Grant * loan village $=0$ (Year 1$)$ shows the p value of the test of whether the total effect of grants in loan villages is statistically different from zero.

2 See the notes of Table 2.1 for details on specification.

3 All columns also include Baseline Social Integration * Loan village * year 1 and Baseline Social Integration * Loan village * year 2 controls. Column (5) additionally includes Baseline profits* Loan village * year 1 and Baseline profits * Loan village * year 2 controls.

4 Risk averse is an indicator for the household choosing the safe lottery, which about half the sample seleted. Large household is 6 or more adults in the household.

5 Other household structure controls include: an indicator for the presence of an extended family and the number of children in the household. 
Figure 1: Experimental Design

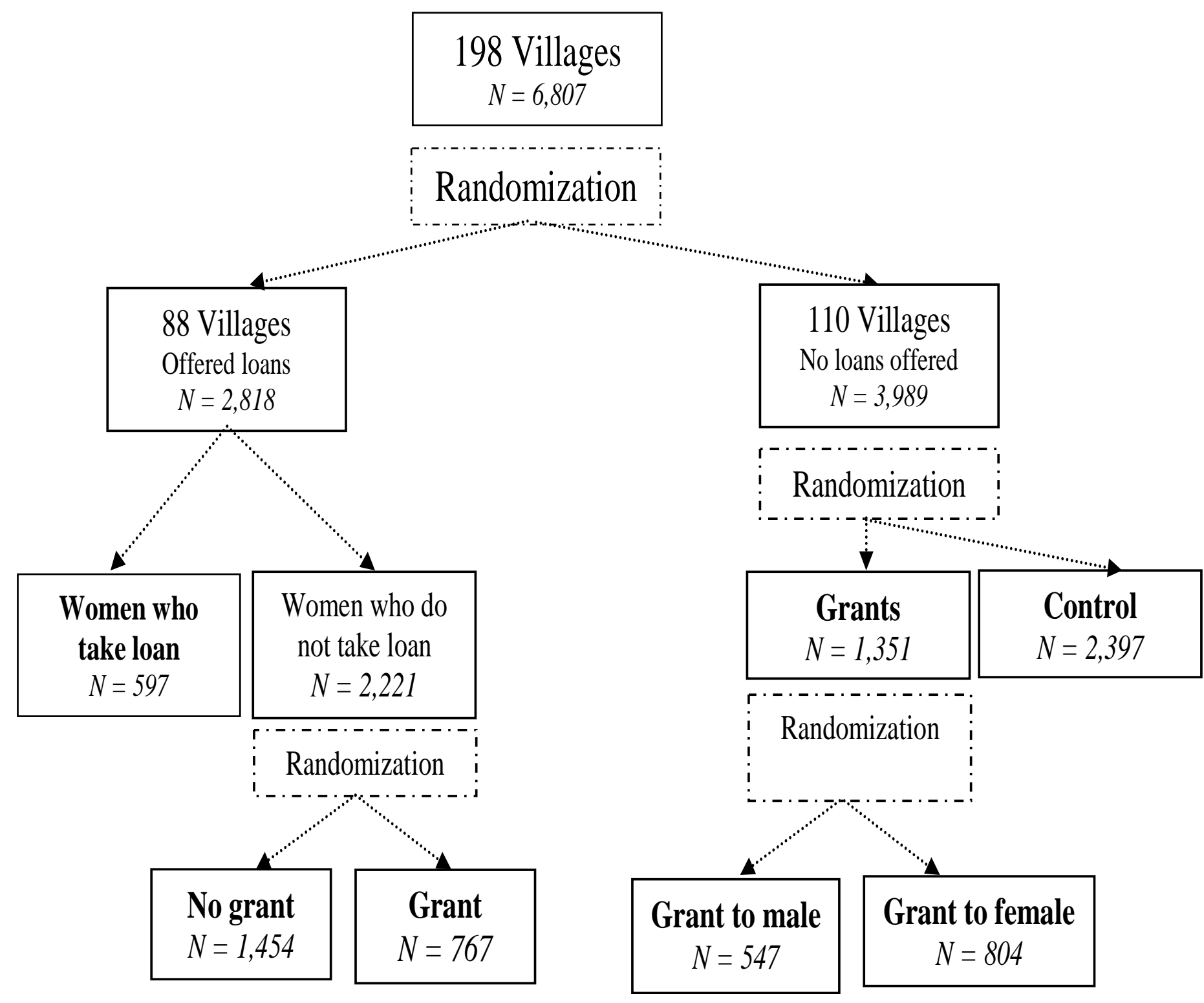


Figure 2: Timeline of the study

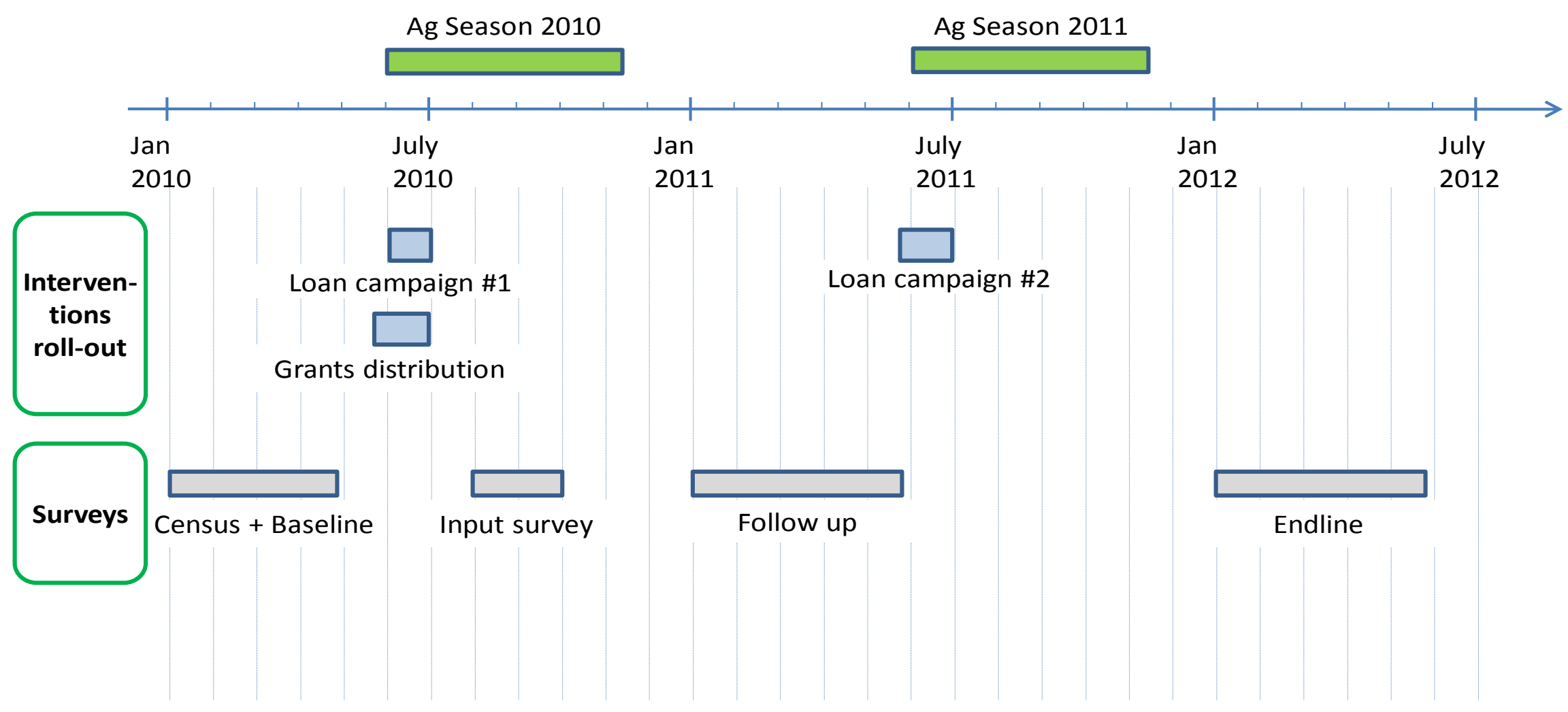

Notes

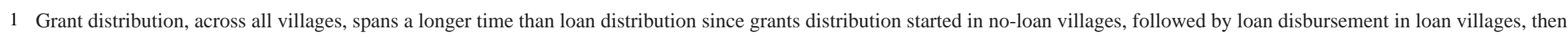
grants in loan and some no-loan villages. 
Figure 3: Baseline characteristics of clients vs. non-clients in loan treatment villages

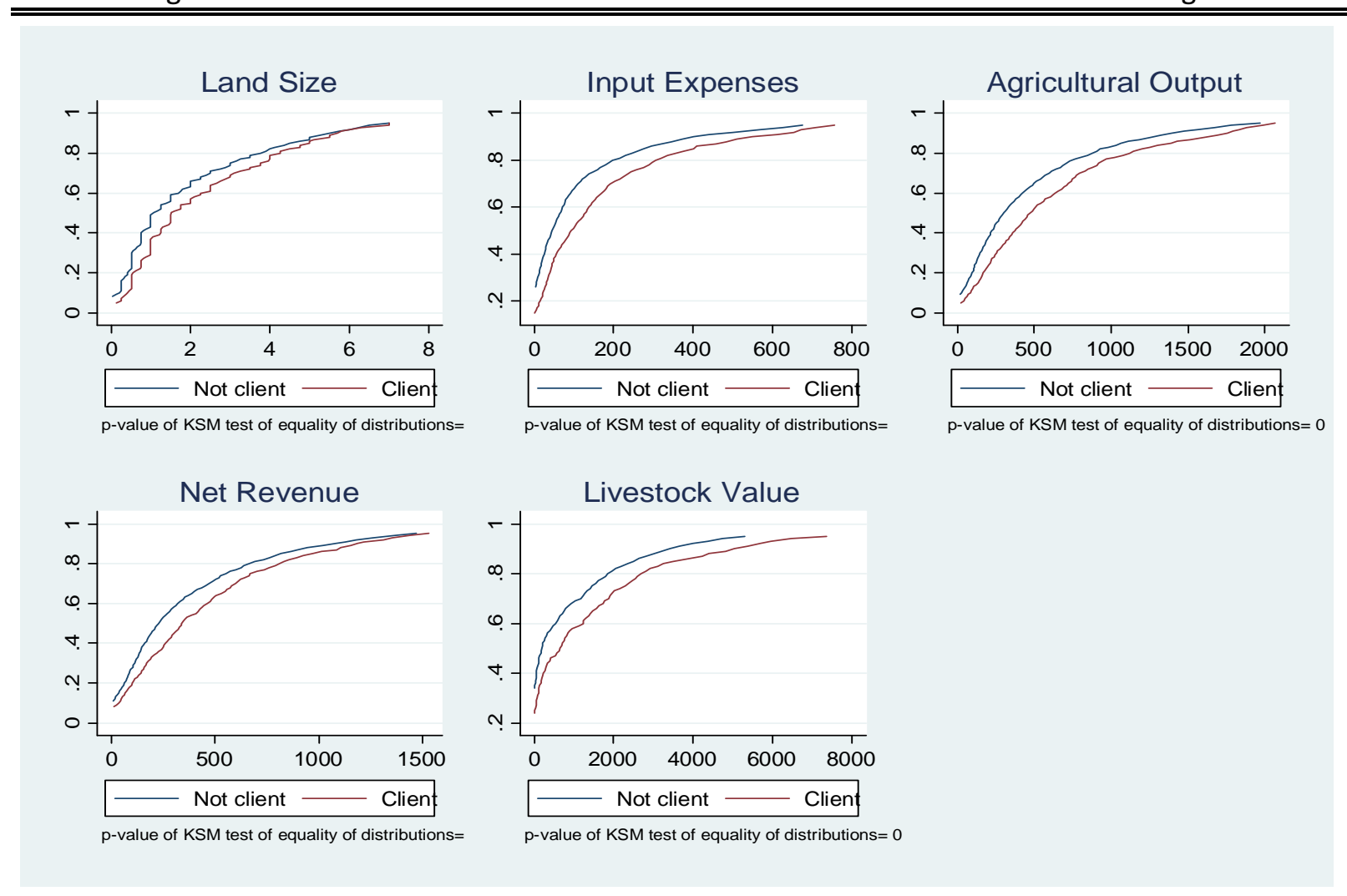


Figure 4: Selection into borrowing

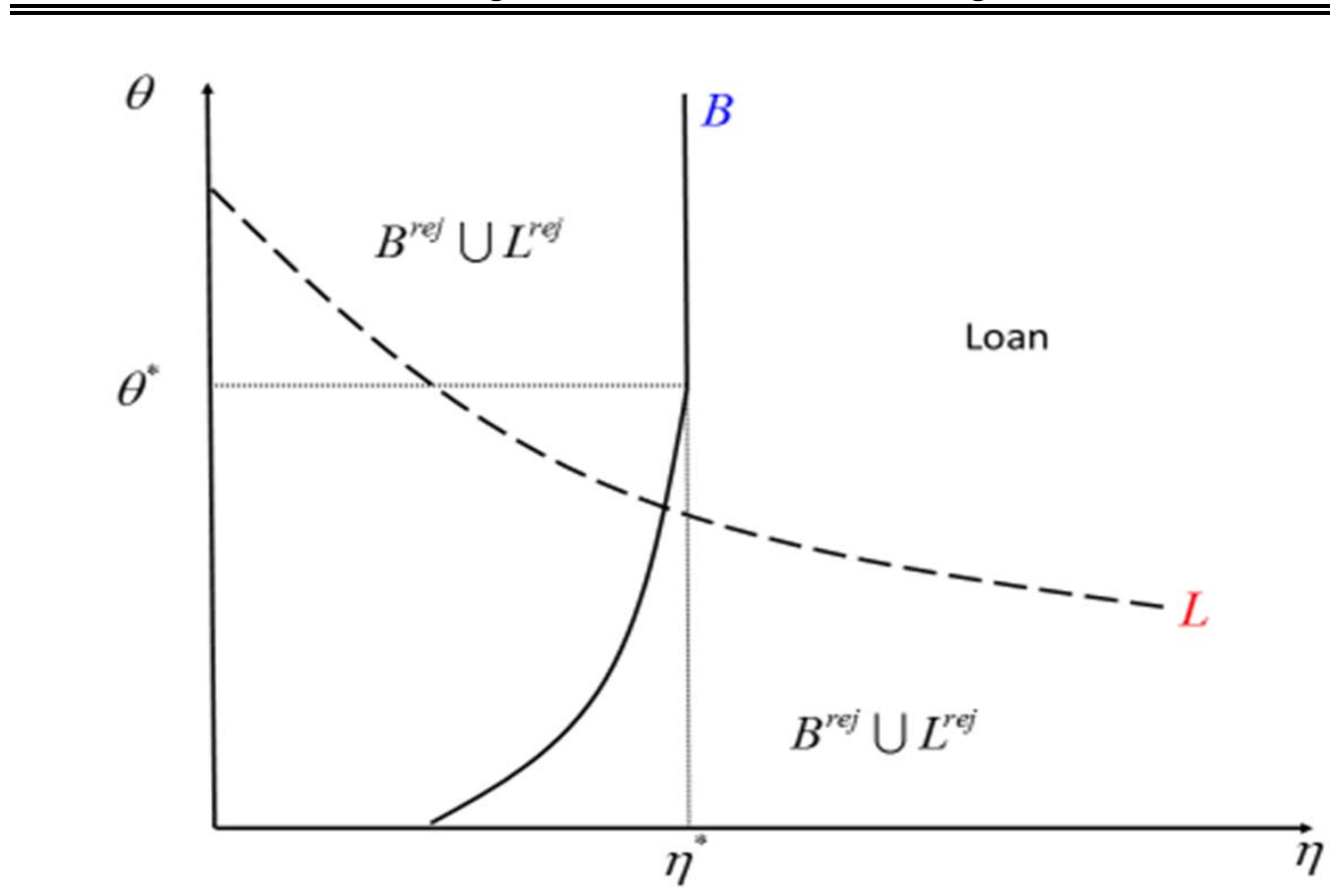


Figure 5: CDF of Net Revenue

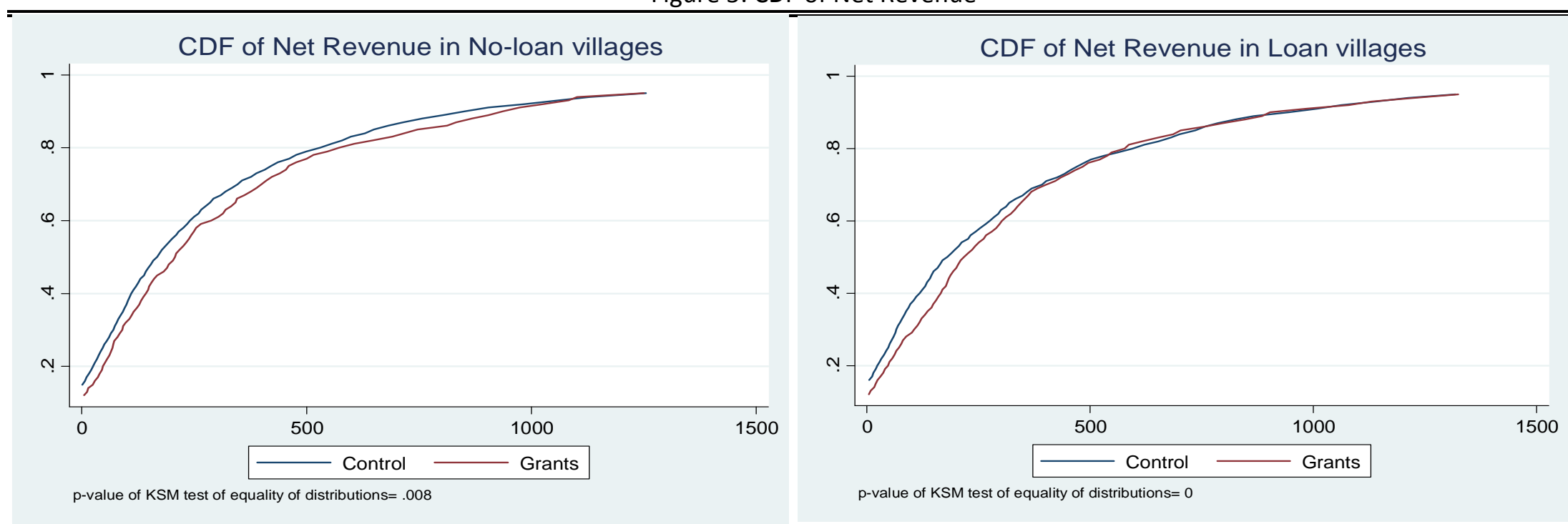


Appendix Table 1: Balance check

\begin{tabular}{|c|c|c|c|c|c|c|c|c|c|c|c|c|}
\hline & \multicolumn{4}{|c|}{ Loan vs no-loan villages } & \multicolumn{4}{|c|}{ Grants vs no-grants in no-loan villages } & \multicolumn{4}{|c|}{ Grants vs no-grants in loan villages } \\
\hline & $\begin{array}{c}\text { Mean of } \\
\text { control } \\
\text { group }\end{array}$ & $\begin{array}{l}\text { Difference } \\
\text { between T } \\
\text { and C }\end{array}$ & p-value & $\mathrm{N}$ & $\begin{array}{c}\text { Mean of } \\
\text { control } \\
\text { group }\end{array}$ & $\begin{array}{c}\text { Difference } \\
\text { between } \mathrm{T} \\
\text { and C }\end{array}$ & p-value & $\mathrm{N}$ & $\begin{array}{c}\text { Mean of } \\
\text { control } \\
\text { group }\end{array}$ & $\begin{array}{l}\text { Difference } \\
\text { between } \mathrm{T} \\
\text { and } \mathrm{C}\end{array}$ & p-value & $\mathrm{N}$ \\
\hline Household size & 7.41 & 0.03 & 0.76 & 6,828 & 7.43 & -0.06 & 0.62 & 3,151 & 7.37 & -0.05 & 0.75 & 2,415 \\
\hline Land & 1.92 & 0.22 & 0.03 & 6,856 & 1.92 & 0.04 & 0.68 & 3,174 & 2.09 & -0.00 & 0.96 & 2,422 \\
\hline Days of family labor & 139.41 & -0.13 & 0.98 & 6,858 & 139.61 & 2.91 & 0.60 & 3,165 & 133.69 & 4.94 & 0.29 & 2,426 \\
\hline Days of hired labor & 11 & 1.02 & 0.32 & 6,856 & 10 & 0.08 & 0.91 & 3,170 & 11 & -0.56 & 0.45 & 2,419 \\
\hline Input expenses & 126.95 & 17.68 & 0.13 & 6,856 & 127.49 & 9.80 & 0.25 & 3,172 & 138.55 & 0.55 & 0.95 & 2,422 \\
\hline Output & 523.02 & 36.67 & 0.24 & 6,856 & 523.74 & 5.07 & 0.84 & 3,176 & 537.61 & 11.06 & 0.66 & 2,415 \\
\hline Livestock value & $1,520.29$ & -120.52 & 0.28 & 6,924 & $1,515.83$ & 2.63 & 0.98 & 3,199 & $1,389.71$ & -36.17 & 0.79 & 2,448 \\
\hline Has a Business & 0.54 & 0.01 & 0.67 & 6,924 & 0.53 & 0.02 & 0.35 & 3,200 & 0.54 & 0.01 & 0.61 & 2,447 \\
\hline Monthly non-food expenses & 39.48 & 0.18 & 0.92 & 6,568 & 39.75 & -0.83 & 0.52 & 3,041 & 38.82 & 0.58 & 0.68 & 2,322 \\
\hline Male Age & 46.57 & 0.19 & 0.66 & 6,427 & 46.67 & -0.35 & 0.50 & 2,947 & 45.93 & 0.53 & 0.31 & 2,272 \\
\hline Male is Illiterate & 0.77 & -0.01 & 0.45 & 6,562 & 0.78 & -0.00 & 0.82 & 3,015 & 0.77 & 0.01 & 0.58 & 2,321 \\
\hline F- test for joint significance & & & & 0.26 & & & & 0.91 & & & & 0.67 \\
\hline
\end{tabular}


Appendix Table 2: Attrition

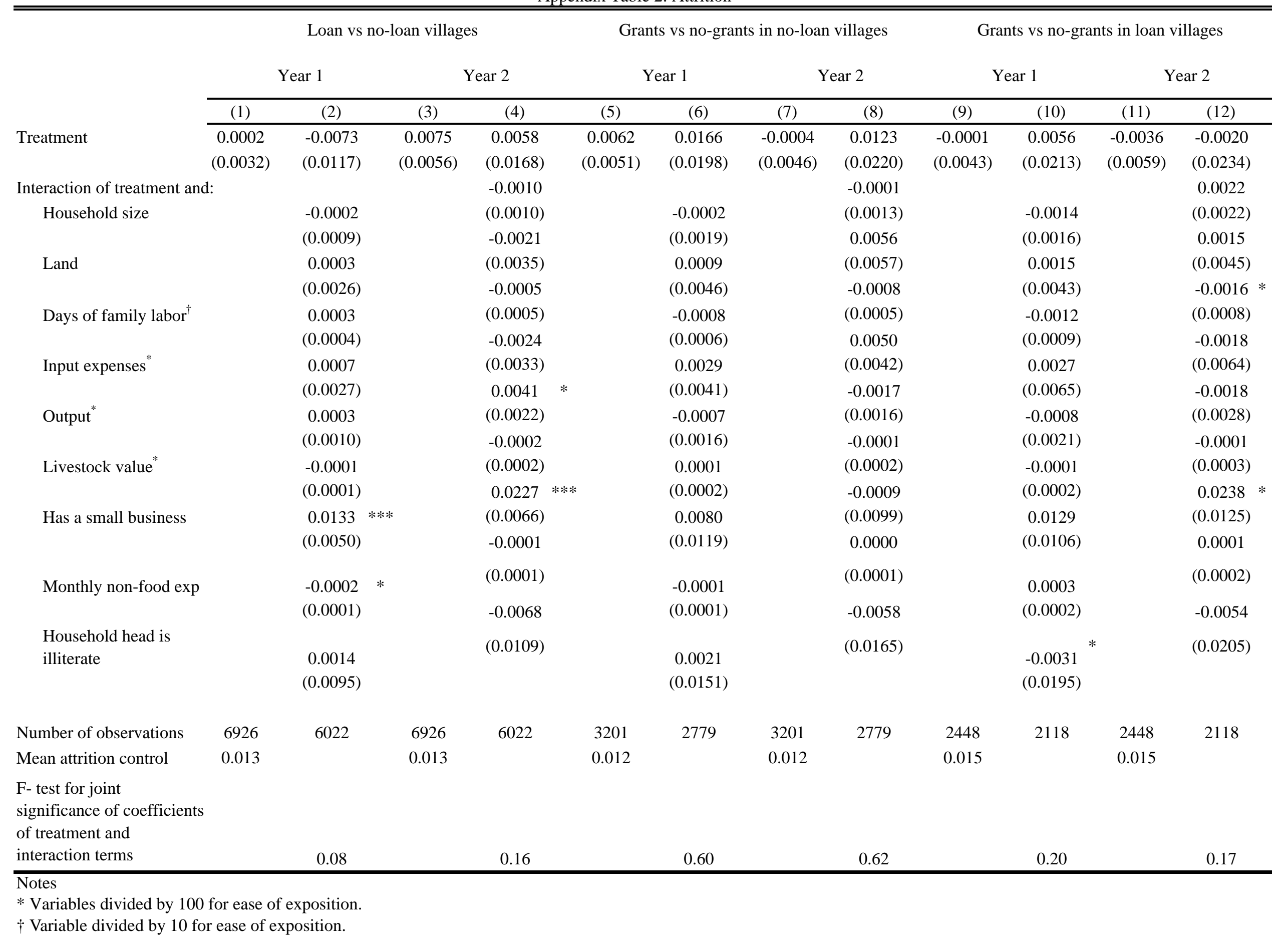


Table A3: Timing robustness (No-loan villages)

\begin{tabular}{|c|c|c|c|c|c|c|}
\hline & \multicolumn{3}{|c|}{ Index } & \multicolumn{3}{|c|}{ Land Size } \\
\hline & (1) & (2) & (3) & (4) & (5) & (6) \\
\hline \multirow[t]{2}{*}{ Date (linear) } & 0.00094 & 0.00290 & & 0.002 & 0.005 & \\
\hline & $(0.004)$ & $(0.008)$ & & $(0.011)$ & $(0.023)$ & \\
\hline \multirow[t]{2}{*}{ Date squared } & & -0.00007 & & & -0.00011 & \\
\hline & & $(0.000)$ & & & $(0.001)$ & \\
\hline \multirow[t]{2}{*}{1 if before June 1st } & & & -0.045 & & & -0.176 \\
\hline & & & $(0.140)$ & & & $(0.407)$ \\
\hline \multirow[t]{2}{*}{ Revisit to Village } & -0.022 & -0.007 & -0.034 & 0.124 & 0.147 & 0.051 \\
\hline & $(0.106)$ & $(0.119)$ & $(0.121)$ & $(0.307)$ & $(0.344)$ & $(0.351)$ \\
\hline Observations & 787 & 787 & 787 & 774 & 774 & 774 \\
\hline Fixed effects & None & None & None & None & None & None \\
\hline
\end{tabular}

Notes

1 Index includes: land area, number of family labor days, number of hired labor days, an indicator for whether fertilizer was used, value of fertilizer expenses, value of other chemical expenses, value of al input expenses, value of harvest, and profits.

2 Sample includes only grant recipients in no-loan villages. 
Appendix Table 4: Additional Outcomes

Panel A. Grant recipients vs control

Grant - year 1

Grant * loan village - year 1

Grant - year 2

Grant * loan village - year 2

Grant + Grant * loan village $=0($ year 1$)$

Grant + Grant $*$ loan village $=0$ (year 2$)$

$\mathrm{N}$

Mean of control (year 1)

SD (year 1)

Panel B. Loan villages vs control

Loan village - year 1

Loan Village - year 2

$\mathrm{N}$

Mean of control (year 1)

$\mathrm{SD}$ (year 1)

Business
Profits: 12
months

(1)

21.49

(13.75)

$-28.87$

(17.35)

42.38

(18.53)

$-18.88$

(27.01)

0.486

0.233

10740

224.57

366.80

2.45

(19.92)

22.46

(31.37)

8594

230.83

371.64

Intra HH
Decision-
making
Index

(2)

Community

Action Index

Social

Capital

Index

(3) (4)

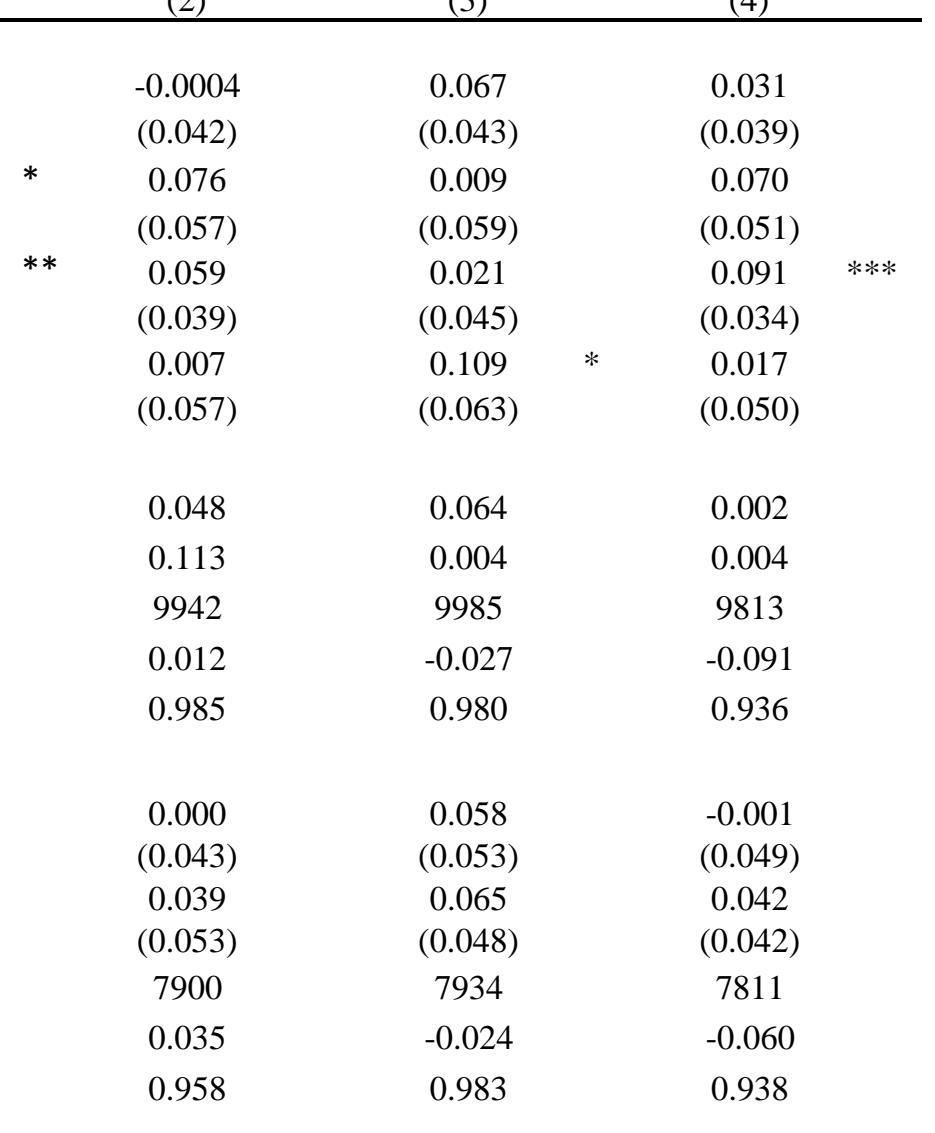

Notes

1 Rows showing Grant + Grant * loan village $=0$ (year 1 ) shows the p value of the test of whether the total effect of grants in loan villages is statistically different from zero.

2 See the notes of Table 2.1 for details on specification. 